\title{
Multiple Causes of Dementia as Engineered Senescence
}

\author{
Mario D. Garrett
}

\begin{abstract}
All traumas-cranial, cardiovascular, hormone, viral, bacterial, fungi, parasites, misfolded protein, genetic, behavior, environmental and medication—affect the brain. This paper itemizes studies showing the many different causes of dementia including Alzheimer's disease. Causes interact with each other, act sequentially by preparing the optimal conditions for its successor, initiate other diseases, allow for other traumas to accumulate and degrade protective features of the brain. Since such age-related cognitive impairment is not exclusively a human attribute there might be support for an evolutionary theory of dementia. Relying on theories of antagonistic pleiotropy and polymorphism, the brain has been designed to sequester trauma. Because of increased longevity, the shortterm tactic of sequestering trauma becomes a long-term liability. We are engineered to sequester these insults until a tipping point is reached. Dementia is an evolutionary trade-off for longevity. We cannot cure dementia without understanding the overall biology of aging.
\end{abstract}

Index Terms-Dementia, etiology, engineered senescence, evolution, Alzheimer's

\section{INTRODUCTION}

To cure dementia, we must first define and understand the causes of each variant of the disease. By knowing the cause/s of the disease potential cures can then be explored. Despite more than a century of mistakenly looking at amyloid plaques followed by neurofibrillary tangles, we have again started questioning alternate causes of dementias. Such enlightenment did not come by an orderly and coordinated national neurobiological research Guidelines [1] or Framework [2]. This realization came because of an unrelenting trickle of individual clinical evidence that has emerged in the last two decades, despite the lack of U.S. federal funding. This paper aims to collate and summarize these studies by summarizing all known causes or correlates of dementia. Overwhelming clinical evidence has now accumulated to reappraise our current focus on the Amyloid Cascade hypothesis [3]. Instead of a competing theory, a general theory of engineered senescence is dawning as an alternative explanation. Such an approach will eventually dictate that neurobiology has to accommodate senescence as an engineered biological factor in disease etiology. A euphemism that at its core requires that science understands the biology of aging. Dementias can play a variable role in the process of aging, and although dementia and the speed of diminished capacity is not part of aging, aging is part of dementia by contributing reduced resilience to infection and trauma.

\section{VARIANTS OF DEMENTIA}

Out of all dementias, Alzheimer's disease (AD) reigns as the most popular dementia diagnosis by clinicians. The other common dementias include vascular dementia; Lewy body dementia; frontotemporal dementia; normal pressure hydrocephalus; Parkinson's disease dementia; and Creutzfeldt-Jakob disease (sporadic/iatrogenic/variant/familial) [4]. More than 95 percent of cases of dementia are attributable to Alzheimer's disease, vascular dementia, Lewy body, and frontotemporal dementia. Rarer forms of dementia estimated at 5 cases per 10,000 in the community [5] include the following variants [4]:

A. Degenerative causes: Familial Alzheimer's disease; Pure hippocampal sclerosis; frontotemporal lobar degeneration; primary progressive (non-fluent) aphasia; Semantic dementia; Progressive supranuclear palsy (SteeleRichardson-Olszewsky syndrome); Corticobasal degeneration; Multiple system atrophy (Shy-Drager syndrome); Amyotrophic lateral sclerosis/motor neuron disease (Lou Gehrig's disease); Huntington's disease; Ataxias (spinocerebellar ataxias, Friedreich's ataxia); Polycystic lipomembranous osteodysplasia with sclerosing leukoencephalopathy-Nasu-Hakola disease; Wilson disease; neuronal ceroid lipofuscinoses-Kufs disease; Gaucher disease (2 and 3); Fragile X syndrome; Fabry disease; Limbic encephalitis (LATE); Niemann-Pick disease Type C; and Spinocerebellar ataxia.

B. Vascular causes: Multi-infarct dementia; Single-infarct (post-stroke) dementia; Subcortical dementia; Cerebral autosomal dominant arteriopathy with subcortical infarcts and leukoencephalopathy-CADASIL; Binswanger's disease; Cerebral amyloid angiopathy; Creutzfeldt-Jakob disease-sporadic/iatrogenic/variant/familial; Fatal familial insomnia; and Gerstmann-Straussler-Scheinker disease.

C. Parasitic infections: Lyme dementia; Cerebral toxocariasis; and McLeod syndrome Neurocysticerosis.

D. Viral infections: herpes simplex virus type 1 and 2; Epstein-Barr virus; Viral meningitis; HIV-related dementia-AIDS dementia complex; Progressive multifocal Leukoencephalopathy; Subacute sclerosing panencephalitis; herpes virus types 6/7; cytomegalovirus; and varicella-zoster virus.

E. Bacterial infections: Tuberculous meningitis; Meningococcal meningitis; Whipple's disease; and Neurosyphilis.

F. Fungal infections: Cryptococcal meningitis.

We might not see these rarer types of dementias in day-to-day clinical settings, but they can contribute to our understanding of the disease/s that result in dementia. 


\section{III.}

\section{Correlates AND CAUSES OF DEMENTIAS}

Funding priorities established by the U.S. National Institute on Aging and other federal agencies dictate that most research focuses on Alzheimer's disease (AD). However, the result of silo research - studying each disease in isolation-leads to a cul de sac [6-8]. Because of the focus on $\mathrm{AD}$, most research remains fixated on plaques and tangles ignoring the diversity of other causes. Whereas AD is exclusively defined by betaamyloid plaques and neurofibrillary aggregates of hyperphosphorylated tau (referred to as plaques and tangles) [7] other dementias (and other diseases) similarly show plaques and tangles in the brain [6]. The difference between dementia and $\mathrm{AD}$ is more political rather than clinical or neurological [7].

Prominent gerontologists have pushed back against silo research [9]. A review of the literature on causes of dementia quickly instills the awareness of how interconnected these disease processes are. Some reviews [10] have implicitly pointed to this interconnectedness of causes of dementia. Vascular health and inflammatory responses remain the most common thread in the development of dementias. Despite this clue for direct intervention, there is very little coordination at the U.S. federal level to consolidate this type of research with AD research. The causes are complex-as defined in this paper-and therefore simple solutions will continue to elude us.

This study contributes to exposing the complexity of dementia through a review of different correlational studies. Other than animal studies, especially with mice engineered to have a specific expression of dementia (plaques and tangles), there has not been one methodological study looking at longitudinal studies that track changes in biomarkers and cognition to define the causal relationship between them. Such a serious omission will hold back future research and exposes a flaw in research methodology. By looking at all correlational studies, as this review intends to do, the overall complexity of dementias can be appreciated. There is no theoretical basis for this review. The review is organized and presented based on major body areas, type of infection, and other factors. These are presented separately. The challenge for subsequent research is to define how each of these causes interact.

\section{Graph: Validated causes of Dementia}

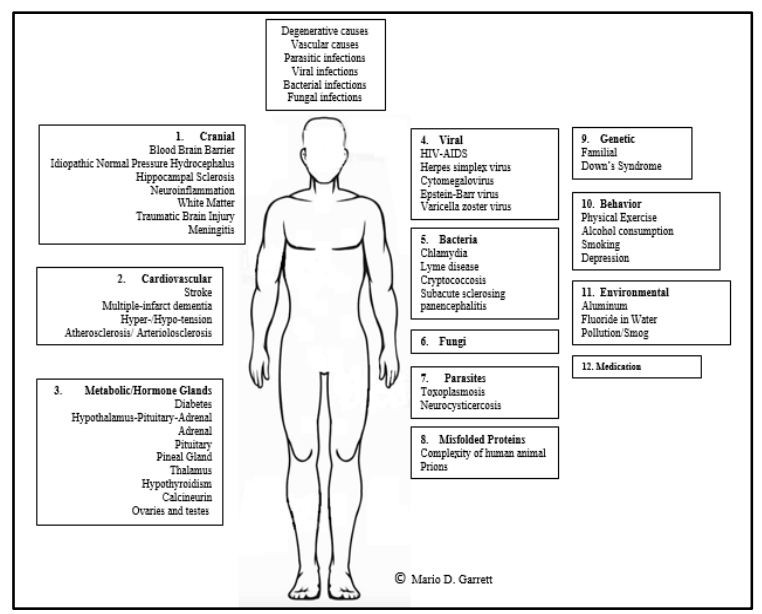

Looking at the body-moving from the brain to the heart, then to hormone glands, exposure from bacteria, fungi, parasite, infections, then finally to the genetic, behavior and environmental factors - all have been implicated as causes of dementia. We can moderate and mediate some of these causes while others remain more pre-determined. There are many causes, predispositions, resilience, interactions and temporal factors that determine the start and progression of dementia, providing a testament to the complex character of the disease. There is no "dementia switch" that can be switched on or off. Some dementias are simple while others are more complex. Some dementias intermix having multiple causes, some are sequential follow from one another, while some infections or trauma reduce resilience resulting in the promotions of subsequent diseases (immunosenescence).

Conceptually if we see cancer as engineered proliferation, dementia occupies an opposing position of this spectrum with engineered senescence. The unrelenting clinical evidence presented here attests to this fact that dementia is engineered death. Although all these studies are correlational, the overall and persistent message is that dementia can be caused by many factors and highlighting these factors should deepen our understanding of the disease.

\section{CRANIAL}

\section{A. Blood-Brain Barrier}

A tightly sealed layer of endothelial cells surrounds the brain and forms the blood-brain barrier (BBB). The $\mathrm{BBB}$ is a barrier that actively transports molecules from and to the brain creating a balance and protecting the brain from neurotoxins and pathogens. An early BBB breakdown has been shown to correlate with $\mathrm{AD}$ [11] and other neurological diseases including Parkinson's disease, Huntington disease, amyotrophic lateral sclerosis, multiple sclerosis, HIV-1associated dementia and chronic traumatic encephalopathy [12]. BBB dysfunction results in greater permeability, dysfunctional active pumps and microbleeds disturbing the integrity of the brain's biological environment [13].

In particular, cerebral microbleeds have been shown in one in four individuals with mild cognitive impairment (MCI) and 45-78 percent of individuals with early $\mathrm{AD}$ [14-16] and confirmed in cohort studies [17] and postmortem examination [18]. It is difficult to separate such microbleeds and cognitive decline from more general vascular events, including (hemorrhagic) stroke [19].

\section{B. Idiopathic Normal Pressure Hydrocephalus}

Idiopathic Normal Pressure Hydrocephalus (iNPH) is an unknown cause of pressure in the ventricles of the brain that is not due to high blood pressure. The ventricles are pockets inside each hemisphere of the brain that are filled with fluid that do not drain as they should and therefore create increased pressure that then compresses healthy glial cells. This disease is expressed clinically through gait impairment, cognitive decline, and urinary incontinence. In a population study, people with probable iNPH had a 3.8 higher chance of dying within five years and a 2.8 higher chance of developing dementia when compared with controls [20]. A recent study 
found that at least 9 percent of nursing home patients with dementia have iNPH [21]. While among a group of 70-year old Japanese living in the community, the rate of iNPH was 1.2 percent [22]. Similarly, in the USA community older adults seen at the Mayo Clinic 1 percent had suspected iNPH [23].

One possible reversal of the effects of iNPH is to place a shunt - a hollow tube - that drains excess fluid out of the ventricles. This intervention has mixed results in reversing dementia. Some report no cognitive improvement [23] suggesting that since $\mathrm{AD}$ is already present the benefit of shunting is too late. While other evidence indicates that patients benefit equally from shunting regardless of the presence of AD pathology [24]. Shunt surgery may lessen the overall burden of functional disability and slow what would otherwise be an accelerated trajectory of neurological decline among patients with iNPH and AD [25].

\section{Hippocampal Sclerosis}

Hippocampal sclerosis (HS), first described in 1880 by Wilhelm Sommer, refers to severe neuronal and glial cell (white cells) loss in the hippocampus that accompanies many diseases including AD. Prevalence estimates of $\mathrm{HS}$ in autopsy-confirmed dementia samples have varied between 0.4 percent and 24.5 percent [26]. HS is likely confused by clinicians with Alzheimer's disease. One defining feature of HS is the misfolded protein TDP-43 as a potential causal factor related to increased rates of hippocampal atrophy [27]. HS may also contribute to non-AD dementia among older adults [28]. HS is implicated in the latest variant of dementiaLATE [29].

\section{Neuroinflammation}

There are cognitive consequences when inflammation of the nervous tissue persists. Inflammation occurs in response to trauma (brain injury, environmental assault, misfolded and aggregated proteins) triggering an innate immune response, releasing inflammatory mediators, that contribute to dementia and $\mathrm{AD}$ progression and severity. In the earliest stages of $\mathrm{AD}$, neuroinflammation initiates the production of microglia - the initial responders to pathogens or tissue damage and are responsible for initiating an inflammatory response. This inflammatory response might also contribute to amyloid deposition [30] and may also interfere with clearance (phagocytic) of debris in the brain [31].

\section{E. White Matter}

White matter in the brain is made up of the axons of neurons and glial cells. Unlike neurons, glial cells do not conduct electrical impulses but communicate through chemical messaging. Glial cells - include oligodendrocytes (speed up electrical conductivity of neurons), astrocytes (feed and grow the neurons), ependymal cells (promotes new neurons), Schwann cells (insulates neurons to speed electrical transmission), microglia (clean up debris), and satellite cells (stem cells) - communicate using neurotransmitters. There are 40 different types of neurotransmitters, and while neurons transmit messages by electricity, at the end of the neuron they must use neurotransmitters to communicate across synapses.
Glial cells, therefore "monitor" neuronal communication. Whereas neurons signal serially, glial cells transmit parallel across their immediate surroundings. Damage to glial cells, therefore, have a direct and radical effect on the role of neurons. The uniqueness of white matter injuries ("axonal shearing") in contrast to neuronal damage, is that white matter injuries are fast-growing (and liable to tumors) and may be reversible. Glial cells are the most abundant cell types in the central nervous system. In the brain, glial cells are more numerous than nerve cells by a ratio of perhaps 3 to 1 [32].

Although dementia and $\mathrm{AD}$, in particular, are referred to as a neuronal disease, white matter hyperintensities in the brain have a dose-effect relationship with dementia and disability [33]. Technically referred to as leukoaraiosis, white matter degradation is associated with cognitive impairment, tripling the risk of stroke and doubling the risk of dementia [34]. Even in $\mathrm{AD}$, small vessel disease, as part of vascular problems, may be of greater importance than amyloid itself [33]. Both white/grey matter microinfarcts were significantly more common in vascular dementia [35].

Degradation of white matter is evident in $\mathrm{AD}$, in semantic dementia, and frontotemporal dementia. This degradation seems to primarily occur in the corpus callosum - the bundle of nerves that connect the two brain hemispheres [36] - and in the medial temporal lobe which sits below it and includes the hippocampus. The medial temporal lobe is a complex bundle of separate organs where damage to one part (medial) tends to express itself as $\mathrm{AD}$ whereas damage to another part (temporal) is closely associated with semantic dementia [37]. Leukoaraiosis involves mostly demyelination, reactive gliosis, and arteriolosclerosis. Although the reduced speed of mental processes is the most characteristic sign, attention, concentration, and verbal and visual memory are also affected and might contribute to vascular dementia [38].

\section{F. Traumatic Brain Injury}

Concussion or mild traumatic brain injuries (MTBI)incurred through falls, motor vehicle accidents, trauma from explosives, shaking, and sports-related activity-account for seventy-five percent of all traumatic brain injuries sustained in the United States [39]. Traumatic Brain Injury is the leading cause of death and disability among young individuals and a risk factor for subsequent development of Alzheimer's disease in later age [40,41]. MTBI is seen at all ages from youth [42] to adults [43], including military soldiers [44]. Both animal and human studies show that head trauma initiates microglial activation that starts a neuroinflammatory reaction that can persist for months and years [45]. Sustaining only one or two MTBI have permanent neurological repercussions [46] that can lead to dementia later in life [47-49]. In the past head trauma was so common as a cause of dementia that a special term "pugilistic dementia" was applied to boxers and their late-life outcomes [50].

\section{G. Meningitis}

Meningitis is an inflammation (swelling) of the protective membranes covering the brain and spinal cord. It can be a fast and fatal disease. There are many causes of this swelling, including bacterial or viral infection or through injuries, 
cancer, certain drugs, and infections. In a review of infectious causes of dementia [51] fungal cryptococcal meningitis was included, although it is likely that all meningitis can cause dementia in the long-term. However, a bacterial infection such as tuberculous meningitis [52] and meningococcal meningitis /herpetic meningitis [53] have also been shown to contribute to dementia and Alzheimer's disease. Out of the precipitating factors for delirium, meningitis increased the odds ratio by more than 20-fold of developing dementias [53]. Streptococcus pneumonia, neisseria meningitidis, and listeria monocytogenes are the most common causes of bacterial meningitis accounting for 70 percent, 10 percent, and 5 percent of cases respectively [54]. Some of these common bacterial meningitides have also been correlated with dementia (e.g. streptococcus pneumonia) [55].

\section{CARDIOVASCULAR}

Vascular dementia is the most common dementia after AD, accounting for 15 percent of cases [56]. There are many different variants of Vascular dementia that include: multiinfarct dementia (multiple small strokes or single infarct dementia caused by a single major stroke with hippocampal damage); Small vessel dementia (subcortical); Strategic infarct dementia; hypoperfusion dementia (low blood pressure); hemorrhagic dementia (stroke); hereditary vascular dementia (CADASIL); and Alzheimer's disease with cardiovascular disease [56].

Cardiovascular disease (CVD) such as stroke, atrial fibrillation, coronary heart disease, and heart failure are very common in older people and have consistently correlated with AD. Either through common risk factors for both CVDs and $\mathrm{AD}$ and also through direct causal association. For example, cardiac disease causes low blood pressure (hypoperfusion) [57] and brain blood clots [58] both are known causes of AD. A Swedish study found that heart failure was related to an increased risk of dementia, including $\mathrm{AD}$, a risk that was however only slightly reduced with antihypertensive drugs [59]. Similarly, The Framingham Offspring Study showed that even lower cardiac function without heart failure was related to increased rates of dementia [60]. The interconnectedness of diseases can be seen by how CVD is influenced by age, diabetes, stroke, hypertension, cardiac disorders, atherosclerosis, metabolic syndrome and genetics [56]. In turn, Vascular dementia is then associated with mood disorders, psychomotor loss, executive function and memory impairment [56].

Apart from Vascular dementia-where vascular disease directly impacts the neurology of the brain — vascular sequela that includes hypoxia, oxidative stress, mitochondrial function, neuroinflammation, neurodegeneration, and bloodbrain barrier permeability all contribute to dementia [61]. Cerebrovascular dysfunction was implicated at some point during the disease process of dementia [61]. Vascular irregularities act as an initiator of many cascading events [62]. For example, the blood-brain barrier can be compromised by early cerebrovascular disorder [63], vascular dysregulation [64], ischemic vascular damage $[18,65]$ and small vessel disease of the brain [66-68]. Heart failure results in low blood pressure (hypoperfusion) of the brain, which leads to lack of oxygen (hypoxia) and damage to nerve cells [69], increasing the risk of blockage (emboli and lacunae) and white matter lesions that increase the risk of dementia [58,70,71]

\section{A. Stroke}

A stroke occurs when blood is interrupted from going to the brain either through rapture or blockage. Stroke is one of the leading causes of disability, dementia, and death in the United States [72]. While many stroke victims improve, others deteriorate. Three months after a stroke, twenty-five to thirtythree percent of patients manifest dementia, and an even greater proportion exhibit cognitive impairment short of dementia [73]. In The Framingham Study stroke reportedly doubled the risk of dementia, even after adjusting for age, sex, education, and exposure to individual stroke risk factors [74]. Very little is known about stroke's discriminating factor for dementia. Most preventive measures such as lowering of blood pressure, statins, neuroprotective drugs, and antiinflammatory agents have variable efficacy, while lifestyle changes such as physical activity, and cognitive training still await large controlled trials [73].

Although the severity of stroke is associated with more negative outcomes, interventions have been shown to have disappointing outcomes in therapeutic trials in post-stroke studies [75]. One national study found that after two years of intensive control and compliance with medication, regular blood pressure monitoring, diet changes, and increased physical activity there was a slight but non-significant improvement in reducing cognitive decline [76]. Better results have been obtained in preventing stroke to reduce the likelihood of cognitive decline and dementia [77]. Once the stroke has occurred few therapeutic interventions have been shown to reduce cognitive decline including the use of anticlogging agents, such as recombinant tissue plasminogen activator, that is part of the guidelines for post-ischemic stroke treatment. Few post-stroke interventions have shown positive outcomes. The stroke penumbra - a shadow surrounding the dead cells caused by the stroke-reflects the beginning of cascading cell senescence across the whole brain. This influence is determined by the process of diaschisis - where distant parts of the brain connected to the damaged area are deprived of stimulation and are themselves then prone to atrophy. Physiotherapy that engages other parts of the brain has been shown reverse the penumbra [78].

Older people with an irregular heartbeat (arrhythmia or atrial fibrillation) are more likely to develop $\mathrm{AD}$ mediated by a stroke [79]. Lacunae-where small arteries that provide blood to the brain's deep structures are blocked - is often described as 'silent' stroke since they are asymptomatic but increase the risk of dementia, including $\mathrm{AD}$ [80,81]. With more than a half-million victims of stroke each year in the United States, stroke constitutes an important factor in the etiology and progression of dementias and AD.

\section{B. Multiple-infarct dementia}

In autopsies of people with dementia and AD, 30 percent had microinfarctions, evidence of multiple mini-strokes [82]. The presence of multi-infarcts accelerates cognitive decline in half the patients [83]. 


\section{Hyper-/Hypo-tension}

Blood pressure - the pressure of the blood passing through veins - increases steadily with age [84] although diastolic pressure dips after age 60 [85]. Hypertension (increase pressure) has a reciprocal causal relationship with stroke, coronary heart disease, heart failure, and disability [86]. One quarter to one-third of the adult population in the USA and European countries have hypertension $[87,88]$. Despite the importance of blood pressure among older adults, very few studies have been conducted among older adults, frail older adults and moribund (dying) older adults [86]. While several studies show mid-life hypertension to be related to an increased risk of $\mathrm{AD}[89,90]$ late-life hypertension does not correlate with dementia, whereas hypotension (low blood pressure) does [91]. Blood pressure is both indicative of an underlying shared disease with dementia (e.g., cardiovascular disease), and contributes directly to accelerating dementia either through hyper or hypo-fusion.

\section{Atherosclerosis/Arteriolosclerosis}

Atherosclerosis - deposition of plaques of fatty material on their inner walls of arteries restricting blood flow-and arteriolosclerosis - involving hardening and loss of elasticity of arterioles - play an important role in both coronary heart disease and AD [69]. Atherosclerosis is associated with a higher risk of dementia and AD [69,92]. Moderate-to-severe atherosclerosis was present in 39 percent and arteriolosclerosis in 35 percent of individuals with dementia, the higher the severity of both atherosclerosis and arteriolosclerosis the higher the chances of dementia and $\mathrm{AD}$ [63]. Even when adjusting for $\mathrm{AD}$ and stroke the greater atherosclerosis the greater the cognitive decline [92] supporting a dose-effect interaction. Since atherosclerosis is closely related to vascular health it is not surprising to find that people with mixed $\mathrm{AD}$ and Vascular dementia have higher rates of atherosclerosis when compared with pure $\mathrm{AD}$ or pure Vascular dementia [93]. Like cardiovascular disease, a myriad of different factors contributes to atherosclerosis that includes cholesterol, smoking, diabetes, genetics, and a combination of these and other factors [94].

\section{HORMONE GLANDS}

Endocrine glands are ductless glands that include the pineal gland, pituitary gland, pancreas, ovaries, testes, thyroid gland, parathyroid gland, hypothalamus and adrenal glands that secrete chemical into the blood stream. It has long been documented that metabolic syndrome/diabetes contributes to dementia, vascular dementia, and $\mathrm{AD}$ [95]. What remains unclear is which of the moderating mechanism is responsible whether it is vascular disease, alterations in glucose, insulin, and amyloid metabolism or a combination of some or all these mechanisms [95].

A. Metabolic Syndrome

In a review of the literature [96], metabolic risks had a variable relationship with dementia. This review found that the following were all associated with increased risks of progression of MCI to dementia; hypertension (variable results); adiposity (an association between high BMI and increased risk of dementia in five out of nine studies); cholesterol (in midlife, but not later life is associated with increased dementia risk); and Glycaemic control (diabetes, prediabetes, and metabolic syndrome) [96]. In contrast, another review [97] showed no statistically significant association between Metabolic Syndrome and incident dementia and AD. However, Metabolic Syndrome increased the incidence of pure Vascular dementia and those with mild cognitive impairment that later increased the probability of progression to dementia [97]. It is likely that at a minimum Metabolic Syndrome facilitate conditions that promote dementia.

Controlling midlife glycemia, total cholesterol, high-density lipoprotein cholesterol, triglycerides, insulin resistance had positive outcomes for older subjects, emphasizing the importance of controlling blood glucose levels - regardless of a diagnosis of diabetes - to reduce the incidence of dementia [98]. In contrast, among Japanese older adults, lower BMI was also associated with a higher incidence of dementia [99]. Metabolic Syndrome contributes to dementia but in a non-linear and still indeterminate way.

\section{B. Diabetes}

Diabetes mellitus (Type 2 diabetes) causes insulin desensitivity, leading to a higher concentration of glucose in the blood. This blood imbalance damages nerve cells and other small capillaries in various organs including those in the meningitis surrounding the brain. Diabetes correlates with infarcts and atrophy in the brain $[100,101]$ and a higher risk of dementia and $\mathrm{AD}$ possibly by allowing the accumulation of plaques in the brain [95].

\section{Hypothalamus-Pituitary-Adrenal}

Recent studies have identified a more prominent role in the hypothalamic-pituitary-adrenal /gonadal relationship in regulating hormones that promote $\mathrm{AD}$ [102]. In particular, the hippocampus-derived growth hormone (neuroestradiol) plays a major role in growing new neurons through the activation of neuroblasts - embryonic cells, stem cells, from which nerve fibers originate. Defects in differentiation, integration, and survival of neuroblasts in the hippocampus appear to be an underlying cause of neurocognitive disorders including dementia and AD [103]. The relationship is however more interconnected. The hypothalamus does not function independently and the relationship between the hypothalamus and both the adrenal and pituitary glands is implicated in contributing to $\mathrm{AD}$.

\section{Adrenal}

Corticosteroids, released from the adrenal cortex, affect mood, stress, anxiety, sleep, appetite, as well as cognition [104]. In cognitively healthy subjects, higher cortisol levels have been associated with an increased risk of cognitive decline and AD. Subjects with dementia and Mild Cognitive Impairment due to $\mathrm{AD}$ have been found to have higher cortisol levels than cognitively healthy controls. Elevated cortisol in the brain may also be associated with a more rapid cognitive decline in Mild Cognitive Impairment leading to $\mathrm{AD}[105]$.

\section{E. Pituitary}

The pituitary gland is a pea-sized organ that sits at the base of the brain behind the bridge of the nose. The pituitary gland 
is known as a "master gland" because it produces numerous hormones that communicate and coordinate with various organs in the body, including the brain. Although its role does not directly affect cognition, it does, however, control other organs and functions that impact the development of dementia [106].

A significant increase in serum cortisol levels during the evening- and night-times was found in elderly subjects with dementia. By comparison to Vascular dementia, patients with $\mathrm{AD}$ exhibited the highest cortisol concentrations throughout the day and night. Adrenal cortisol production is regulated by a hormone (ACTH) synthesized in the pituitary gland [106]. The same dose effect was found with ACTH being highest in the AD group followed by Vascular dementia and then senile dementia of $\mathrm{AD}$ type and lowest in unspecified dementias [107].

\section{F. Pineal Gland}

Although sleep patterns can be interrupted by external conditions (nursing home routines, medications, stress, temperature, and other factors), there is also a complex biological sleep metronome that involve multiple brain organs. The principal function of the pineal gland is to generate melatonin that controls sleep patterns (and new bone deposition.) Insomnia and other sleep disturbances are common in patients with neurodegenerative disorders including those with $\mathrm{AD}$, affecting up to 44 percent of patients in clinic and community-based samples [108,109]. Individuals suffering from dementia with Lewy bodies and Parkinson's disease have the highest frequency of sleep disturbances, with 90 percent of patients affected followed by vascular dementia, AD and frontotemporal dementia [110]. Dementia patients have abnormalities in melatonin secretion [111]. Because these brain regions involved in sleep and circadian control are affected early in the progression of the disease [112] this imbalance supports a clinical argument for causality.

\section{G. Thalamus}

A potentially reversible progressive dementia results from a stroke in bilateral thalami [113]. People with different types of dementia had significantly smaller thalami than controls, with frontotemporal dementia and motor neuron disease having the smallest, followed by frontal variant frontotemporal dementia, progressive nonfluent aphasia, primary progressive aphasia, and lastly semantic dementia [114].

\section{H. Hypothyroidism}

The thyrotropin-releasing hormone is short-lived and affects the pituitary gland and the nervous system stimulating arousal and feeding centers of the brain. Cognitive decline due to thyroid deficiency may develop into hypothyroid dementia [115]. Behind, but attached to, the thyroid gland are four tiny glands called the parathyroids. Malfunction through tumor of the parathyroids causes calcium to increase in the blood causing cognitive impairment and dementia. Such causes of dementia and cognitive impairment are reversible [116] but not in all cases [117,118]. The thyroid hormone coordinates brain development in the fetus through neural cell migration and differentiation, synaptogenesis, and myelination. This process influences different brain regions at different times.
Deficiencies in thyroid hormones produce neurological deficits that are responsible for cretinism. In older age dysfunction of the thyroid glans is associated with coronary vascular disease (as a result of increased calcium in the blood) promoting $\mathrm{AD}$ [116]. Clinical studies have shown that both hypo- and hyperthyroidism are correlated with $\mathrm{AD}$, although this association is variable and inconsistent $[119,120]$. AD in turn also affects the thyroid by reducing thyrotropin-releasing hormone secretion [116].

\section{Calcineurin}

The "Calcium Hypothesis" purports that the influx of calcium into the cytoplasm of neurons is an early trigger that starts the cascade of the production of amyloid plaques followed by neurofibrillary tangles [121]. Calcineurin (calcium and calcium-binding protein, a unique protein that manages the balances of calcium in cells) is found in the human brains especially when they have dementia [122]. Levels of calcineurin increase greatly with age, after injury or infection, and in brains of AD patients [123]. Experimental evidence suggests that treating patients with calcineurin inhibitors-in most cases, this is done to prevent organ transplant rejection-have a significantly lower incidence of $\mathrm{AD} /$ dementia as compared to the general population [124]. However, there are ambiguous results with parathyroid surgery showing mixed evidence for improvements in memory, though there is an agreement that positive but limited outcomes are experienced in other cognitive domains [125].

\section{J. Reproductive Organs (ovaries and testes)}

Age-related loss of sex steroid hormones such as testosterone and estradiol could be a risk factor for developing AD [126]. The depletion of estrogens in women and androgens in men increases the vulnerability of the aging brain that contribute to the development of AD [126].

Female sex hormones include estrogen, progesterone, and testosterone. Estrogen is the primary sex steroid hormone that controls the development of secondary sexual characteristics and regulation of the menstrual cycle [127]. Estradiol is a major form of estrogen that affects cognitive functions by regulating hippocampus-based mood and cognitive functions, with an abnormal level of estradiol leading to depression and dementia-related problems $[128,129]$. In some cases, this dementia-related decline can be reversed through estrogen replacement therapy [130]. The role of estradiol implicates the hypothalamic-pituitary-gonadal system as a brainspecific feedback loop [131].

The male sex hormone is primarily testosterone. Several studies report that compared with controls, men with AD have lower levels of testosterone [132,133]. The slow reduction in testosterone with advancing age usually reflects hypogonadism a diminished efficiency of the testicles. Hypogonadism results in raised levels of gonadotropins correlated with AD [134]. However, it remains unclear how $\mathrm{AD}$ is associated with decreased or increased hypothalamopituitary function and how this interacts with age.

The obverse is also reported where high testosterone level is correlated with symptoms of hallucinations, delusions, agitation, irritability and motor activity compared with a lowtestosterone group [135]. It remains unclear whether 
hypogonadism is the cause or the result of $\mathrm{AD}$ or both share a common cause [134]. The gonads for both males and females likely play a role in a complex hormone change in older adults that impacts or reflects changes in cognitive capacity.

\section{VIRAL}

A virus is a non-living multi-cell organ that reproduces inside living hosts by producing thousands of identical copies of the original virus by deceiving the host until it has reached critical levels.

\section{A. HIV-AIDS}

Growing evidence exists for the role of viral infections in dementias, Parkinson's disease, amyotrophic lateral sclerosis, multiple sclerosis, autism spectrum disorders, and $\mathrm{AD}$ are directly implicated in HIV-associated neurocognitive disorders [136]. The primary virus that causes one type of dementia is HIV-AIDS and to an opportunistic infectioncytomegalovirus - that also infects the central nervous system and can cause dementia independently [137].

\section{B. Herpes simplex virus}

Herpes viruses consists of HSV-1, HSV-2, varicella-zoster virus (VZV; HHV-3), Epstein Barr virus (HHV-4), cytomegalovirus (HHV-5), HHV-6A, HHV-6B, HHV-7, and HHV-8. Because patients taking antiherpetic therapy for herpes simplex viruses type 1 and 2 (HSV-1, HSV-2) had a lower risk of $\mathrm{AD}$ and other dementias [138] the role of herpes in $\mathrm{AD}$ research became validated. Once infected, the virus remains in the peripheral nervous system and can have minor expressions through cold sores but usually remains dormant. Most herpes viruses especially HSV-1 and HSV-2 are associated with increased risk for all types of dementia. Herpes can cause encephalitis and affects the same regions of the central nervous system (temporal and frontal cortex, and hippocampus) as those most affected by dementias [139]. Besides, an increased risk of dementia exists when the herpes is present together with the genetic marker of APOE- $\varepsilon 4$ allele [140]. Infection by HSV 1 forms plaques (as a protective function) that are implicated in dementia especially $\mathrm{AD}$ [141].

\section{Cytomegalovirus}

Cytomegalovirus also is known as human herpesvirus-5 (HHV-5) together with Epstein-Barr virus (EBV) are among the most common viruses in humans. Both viruses are members of the herpes virus, and like herpes, once cytomegalovirus infects you it resides in your body for life. In a postmortem study, 93 percent of the patients with vascular dementia (compared to 34 percent of unmatched controls) had cytomegalovirus [142]. Although other studies show no correlation.

In a longitudinal study, cytomegalovirus is associated with cognitive decline and the risk of Alzheimer's disease [143]. Supporting other studies showing correlational association of cytomegalovirus with dementia [144,145]. In contrast, other studies do not find this association [146].

In an 11-year longitudinal study that followed 7,112 Finnish adult population (30 years and older) 84 percent had cytomegalovirus and 98 percent had Epstein-Barr virus. With such high prevalence rates, it would be impossible to find any association with cognitive functioning or with dementia [147] or with another disease. A more recent meta-review cast doubt on the veracity of this research and exposes a lack of methodological rigor exacerbated by the complexity of comorbidities [148].

\section{Epstein-Barr virus}

A meta-analysis with three small samples found an association between Epstein-Barr virus and AD [149]. In contrast, studies looking at Epstein-Barr virus among nonelderly persons and persons with schizophrenia did not detect any association [150]. As with cytomegalovirus that share the same herpes family, because of its high infection rate, it is methodologically complex to differentiate causality for dementia.

\section{E. Varicella-zoster virus}

Similarly, the Varicella zoster virus has a higher occurrence among people with unipolar or bipolar depressive psychoses and senile or atherosclerotic dementia [151]. Controls, schizophrenics or patients with other psychiatric disorders or in groups of healthy people had lower levels of this virus. The varicella-zoster virus was also associated with an increased risk for dementia [152].

\section{BACTERIA}

For centuries, syphilis - a bacterium - existed as the only known external cause of dementia other than older age. “...Dr. Alzheimer found syphilis-related plaques in a 31year-old patient affected with dorsal tabes, who appeared to be mentally intact..." [153, p123]. Syphilis and its terminal expression, syphilis dementia-Neurosyphilis - was very common in the 1900s. Before the introduction of penicillin in 1943, syphilis was a common killer and a main cause of dementia [7] sharing the same plaques and tangles as found in senile (old age) dementia.

\section{A. Chlamydia}

The extremely common bacteria $C$. pneumoniae infects the respiratory tract and lungs and can cause lung disease. It is also found in 90 percent in the plaques of the brain of patients with dementia while in only 5 percent of controls [154] and not found in the brains of individuals with other neurological diseases [155]. It has also been argued that the etiologies of early-onset versus late-onset $\mathrm{AD}$ can be distinguished by $C$. pneumoniae infection with late-onset associated with $C$. pneumoniae [156]. Once the bacterium enters the central nervous system and infects the brain, its long-term residence initiates a chronic inflammatory response, triggering the start and continuation of neuronal death and AD [157].

\section{B. Lyme disease}

Today, the main bacterial threat comes from Lyme diseasecaused by the bacterium borrelia burgdorferi and transmitted to humans through the bite of 23 varieties of infected blacklegged ticks. Lyme disease is the most common vectorborne disease in the northern hemisphere. Its increasing incidence now leads to increased public health concerns [157] since it has been shown to cause some dementia, reported as 
Lyme dementia [158]. Science has not identified the mechanism for the development of Lyme dementia. It remains one of the most prevalent likely future bacterial causes of dementia.

\section{Cryptococcosis}

Helicobacter pylori is a bacterium that enters the body through the digestive tract. After many years, it can cause ulcers in the lining of the stomach or the upper part of the small intestine. For some people, an infection can lead to stomach cancer. Helicobacter pylori infection might also increase the risk of dementia [159] but the available evidence is inconsistent, and longitudinal studies are sparse and when available the evidence is missing [160]. Again, this might be due to the lack of differentiation since Helicobacter pylori are resident in the stomach of half of the world's population [161] and therefore difficult to discriminate.

\section{Subacute sclerosing panencephalitis}

Subacute sclerosing panencephalitis (SSPE) is a progressive neurological disorder of childhood and early adolescence that is caused by the persistent mutant measles virus. Mostly affecting children, the virus causes neurodegeneration, inflammation, and demyelination of the central nervous system resulting in death before the age of three. Although rare, it has been noticed in older adults where SSPE remerges from a dormant state and causes dementia [162].

\section{FUNGI}

Fungi including Alternaria, Botrytis, Candida, Cladosporium, Fusarium, Aspergillus, Davidiella, and Malasseziais are widespread in the brain of AD patients. Candida (the most widespread) is present in 89 percent of $\mathrm{AD}$ patients compared to eight percent for controls [163]. Fungal infections are common associates of dementia and AD. Elevated levels of chitotriosidase, a human chitinase enzyme - a maker for fungal infection - is also a biological marker for $\mathrm{AD}$ and vascular dementia [164]. In central nervous system tissue of people with $\mathrm{AD}$, the highest percentage of infection was from Alternaria and Malassezia. While infection from Aspergillus, Candida, and Davidiella was found in a higher percentage among healthy older adults and younger subjects [165]. There is great heteroscedasticity - increasing variance with age-among these studies. In a review of the literature [166], the abundance of fungal infection is thought to have an evolutionary advantage by holding the fungi infection long enough in the brain to allow humans to be able to reproduce in the short-term, with dementia being the long-term outcome of such fungal hosting.

\section{PARASITES}

Parasites are organisms that live in a host organism, on whom it depends for its survival. In most cases, the parasite harms the host. The most notorious parasite that harms the host is toxoplasmosis. Among mice, the parasite reduces the inhibition of cats ending in a fatal attraction.

\section{A. Toxoplasmosis}

Toxoplasma comes from infection with the Toxoplasma gondii parasite, by eating undercooked contaminated meat, exposure from infected cat feces, or mother-to-child transmission during pregnancy. Toxoplasma infection may be involved in the development of AD through inflammation. Toxoplasmosis was present in 44 percent of AD patients compared to 24 percent among the control groups [167]. In a systematic review, Toxoplasma gondii infection has been recognized as a potential risk for many psychiatric and neurological disorders including Alzheimer's disease but not for Parkinson's disease [168].

\section{B. Neurocysticercosis}

Neurocysticercosis is a parasitic infection in the brain caused by larval of the pork tapeworm. Patients with neurocysticercosis displayed significant impairment in executive functions, verbal and nonverbal memory, constructive praxis, and verbal fluency when compared with controls. Dementia was diagnosed in 12.5 percent of patients with neurocysticercosis [169].

\section{Misfolded PRoteins}

The Human Proteone Project has so far identified 30,057 proteins [170]. Out of these, 34 misfolded proteins have been studied. The Amyloid Cascade hypothesis identifies two as the culprits in $\mathrm{AD}$ [3]. This hypothesis became enshrined in the 2011 Guidelines and later in the 2014 Framework published by the National Institute on Aging and Alzheimer's Association [1,2]. The amyloid cascade hypothesis posits that the deposition of plaques, the amyloid- $\beta$ peptide in the brain - a small beta protein that misfolded and becomes an amyloid - triggers the formation of tangles, hyperphosphorylated tau tangles - a brain-specific microtubule protein. Plaques have been implicated as the trigger while tangles are the bullet in Alzheimer's disease [171].

\section{A. Complexity}

Our body, including our brain, is constantly changing. Within each of the 37 trillion cells [172], there is a constant dynamic activity. Constituting one of four major molecules in the body, proteins - made up of 20 different amino acids - have different combinations. Each combination defines the physical structure that determines its function. Cells within 
specific organs produce specific proteins, although all cells can synthesize some proteins. The Amyloid Cascade hypothesis the primary theory for the cause of AD [3] focusses on amyloid- $\beta$ peptide, a small protein called a beta $(\beta)$ that misfolds and becomes an amyloid. Amyloid refers to how small proteins interact together by combining and forming a solid insoluble mass - they become hydrophobic, shy of water, because of how they fold. Amyloidosis disease includes:

- Amyloidosis-systemic
- Primary systemic
- Ig heavy-chain-associated
- Secondary (reactive) systemic
- Senile systemic
- Hemodialysis-related
- Hereditary systemic ApoAI
- Hereditary systemic ApoAII
- Finnish hereditary
- Hereditary lysozyme
- Genetic cystatin C amyloid angiopathy
- Amyloidosis-localized
- Injection-localized
- Hereditary renal
- Senile seminal vesicle amyloid
- Familial subepithelial corneal
- Cataract

- Medullary thyroid carcinoma
- Neurodegenerative diseases
- Alzheimer's disease
- Parkinson's disease
- Lewy-body dementia
- Huntington's disease
- Spongiform encephalopathies
- Hereditary cerebral hemorrhage
- Amyotrophic lateral sclerosis
- Familial British dementia
- Familial Danish dementia
- Familial amyloidotic polyneuropathy
- Frontotemporal dementias
- Diabetes mellitus
- Atherosclerosis
- Sickle cell anemia
- Other diseases

To date, most of the treatments tested in human clinical trials include those that remove amyloid- $\beta$. Despite the success of these drugs in removing plaque from the brains of Alzheimer's disease patients, the effect on behavior and thinking was negative [173]. Patients who had the misfolded proteins chemically removed did worse in tests $[174,175]$. Clinical evidence supports such conclusions. Approximately half of clinically demented oldest-old people have insufficient neuropathology to account for their dementia $[179,180]$.

In support of this finding, a longitudinal study reported that eight percent of participants who did not have dementia, nevertheless, when they died, their brain showed the most severe neuropathology [176-178]. While approximately thirty to fifty percent of older adults without dementia meet the neuropathological criteria for Alzheimer's disease [181183]. It seems that the clinical expression of AD is not solely determined by these misfolded proteins as promoted by the National Institute on Aging [1,2].

Protein misfolding is continuous and "normal" in as many as one in every 7 proteins produced by the body. Proteins can misfold through many mechanisms. The concept of "misfolding" and "errors" are moral not biological judgments. Especially when it is known that amyloids are naturally produced to carry out necessary functions in the body [184]. A $\beta$ can be formed from 18 inappropriately folded versions of proteins naturally present in the body [185].

There are 47 misfolded proteins that have been identified, many more await to be discovered. According to the Amyloid Cascade hypothesis [3], any of these misfolded proteins that find themselves in the brain can cause dementia and AD:

- ABri
- ADan
- Amyloid A protein
- Amyloid $\beta$ peptide
- Apolipoprotein AI
- Apolipoprotein AII
- Apolipoprotein AIV
- Atrial natriuretic factor
- Beta-2 microglobulin
- Calcitonin
- Crystallins
- Cystatin C
- Fibrinogen
- Fused in sarcoma (FUS)
- Gelsolin
- Glial fibrillary acidic protein
- Immunoglobulin heavy chains
- Islet amyloid polypeptide
/(IAPP; amylin)

- Keratoepithelin

- Lysozyme

- Medin (lactadherin)

-Monoclonal immunoglobulin light

chains

- Notch3

- Prion protein

- Prolactin

-Proteins/ tandem glutamine expansions

- rhodopsin

- Seipin

- Serpins

- Superoxide dismutase,

- Tau protein

- TDP-43

- Transthyretin

$\bullet \alpha-S y n u c l e i n$

/(IAPP; amylin)

\section{B. Prions}

Bovine spongiform encephalopathy-better known as mad cow disease - is linked to Creutzfeldt-Jakob's disease (CJD) and Kuru [186]. The hallmark of prion disease is the accumulation of a misfolded protein that is toxic to neuronal cells but without an inflammatory reaction or fever [186]. Between 5 and 10 percent of persons with CJD have a family history of the disease suggesting a genetic predisposition for infection [187].

\section{GENETIC}

\section{A. Familial}

Familial AD occurs in 5.3 per 100,000 persons [188] and accounts for 0.5 percent of all AD cases and usually presents before the age of 65 years (average of 45 years of age) with half carrying mutations in one of the three genes, namely, presenilin 1 (PSEN1), PSEN2, and amyloid precursor protein (APP) [189]. Familial AD supports the Amyloid Cascade hypothesis [3] as these mutations increase the production of amyloid-beta 42, which results in the early onset of AD [190]. What is surprising is that specific genes cause specific disorders. While 16 percent of the Familial AD patients did not present with a memory problem, certain genes cause the inability to perform learned movements/apraxia (caused by APP), disorientation (PSEN20), aggression (APP), seizures, spastic paraparesis, myoclonus, and cerebellar signs (PSEN1) [190].

\section{B. Down's Syndrome}

Down's syndrome - a genetic disorder that results in slow mental development - affects 5.8 million people worldwide and is the most common genetic cause of learning difficulties that eventually contributes to the highest prevalence of dementia under the age of 50 years [191]. Older individuals with Down's syndrome will eventually get dementia-77 percent in people aged 60-69 years and 100 percent in people aged 70 years or older [192]. Different dementias are expressed including $\mathrm{AD}$, multi-infarct dementia and dementia with Lewy bodies [193]. Down's syndrome also contributes to other conditions that by themselves further contribute to dementia including; hypothyroidism, depression, parkinsonism, EEG abnormalities, and late-onset epilepsy [194]. 
How we behave influences our health including our brain health. Physical activity, alcohol consumption, smoking and depression are major factors controlling our health in general and our brain health in particular.

\section{A. Physical Exercise}

Obesity increases the likelihood of bacterial and viral infections that result in inflammation [195]. White fat tissue also contains macrophages that constantly secrete proinflammatory chemicals [196]. Inflammation promotes dementia and $\mathrm{AD}$ that might explain why midlife obesity is correlated with AD [197]. Obesity directly contributes to dementia, but it also shares many of the precursors such as diabetes, high cholesterol diet, reduced physical activity and a sedentary lifestyle [158]. Obesity is also associated with reduced gut bacterial diversity (microbiome) associated with increased levels of inflammation contributing to $\mathrm{AD}$ risk [198].

In contrast, physical activity protects from vascular disease and diabetes and reduces other risk factors that promote AD [199]. Exercise also enriches the blood flow to the brain which could be the reason why the risk for dementia and AD decline with exercise [200].

\section{B. Alcohol consumption}

Alcohol has had a long ambivalent association with mental health. Increasing interest has emerged in the relationship between a history of heavy intake of alcohol correlating with dementias. Emerging evidence is showing that this relationship is independent and not mediated by a history of hypertension, cardiovascular disease, or head injury [201]. Meta-analyses studying the relationship between alcohol consumption and risk of $\mathrm{AD}$ and dementia reported a "J" shaped relationship, with moderate drinking showing moderate protection while heavy intake causes WernickeKorsakoff syndrome a type of dementia. [202].

A history of high alcohol intake - 2 or more drinks a dayhas been shown to increase the risk of Mild Cognitive Impairment and dementias in a large Canadian study [203]; in a US study [204]; and in a Brazilian study [205]. Excessive alcohol use may damage the brain due to toxic effects of alcohol, metabolic changes in the brain, neurotransmitter imbalances and nutritional deficiency injury [201].

\section{C1 Smoking}

Studies have consistently shown a positive link between smoking and dementia and $\mathrm{AD}$ in a dose-response relationship - the higher the rate of smoking the higher the risk of AD [202,206,207]. Also, various longitudinal studies have established smoking as a risk factor for dementia and AD [202]. Both the Rotterdam Study and the Honolulu-Asia Aging Study found this dose-response relationship [206,207]. Smoking contributes to atherosclerosis and has been related to cerebral small vessel disease [208]. Smokers are a third more likely to get dementia reduced to a quarter more likely for those that recently quit, while quitting for 9 years removed the risk of dementia completely [209].

\section{Depression}

A recent meta-analysis demonstrated that late-life depression is a risk factor for Vascular dementia, as it is also for AD [210]. This is relevant as late-life depression is associated with several vascular abnormalities, demonstrable both on brain imaging [211] and pathology [212] and vascular mechanisms that provide a plausible mechanism between depression and Vascular dementia. The correlation of depression with dementia indicates that treating older adults with dementia will need to also address co-occurring depression [213].

\section{ENVIRONMENTAL}

A review of sixty studies found moderate evidence implicating air pollution; aluminum; silicon; selenium; pesticides; vitamin D deficiency; and electric and magnetic fields in the progression of dementia [214]. The main culprits are aluminum, fluoride, and pollution.

\section{A. Aluminum}

Epidemiological studies suggest that aluminum may actively contribute to the onset and progression of dementias [215]. Although causation is still not completely understood, chronic aluminum neurotoxicity can be seen in most dementias [216]. Aluminum toxicity has been shown to cause Dialysis Dementia among patients [217]. Although rare today Dialysis Dementia illustrates how aluminum - one of the most ubiquitous metal elements in the earth's crust - can be neurotoxic and act as an injury that causes dementia [218].

\section{B. Fluoride in Water}

In the largest longitudinal study in this field [218] the risk of dementia was raised between 9 and 12 percent with increasing aluminum and fluoride levels. Fluoride combines with aluminum to form aluminum fluoride, that is then absorbed by the body where it eventually combines with oxygen to form an aluminum oxide or alumina. Alumina is the compound of aluminum that is found in the brains of Alzheimer's disease. A dose-response association was observed between mean fluoride levels and dementia, with dementia risk more than doubled in the highest quartile compared with the lowest [218]. Although aluminum is evident in most brain tissue [219,220] in tissue from 12 donors diagnosed with familial Alzheimer's disease the concentration was found to be extremely high [221]. It seems inevitable that aluminum contributes to the development of $\mathrm{AD}$ [222]. In contrast, clinical trials suggest that lithium may improve cognitive outcomes in groups with mild cognitive impairment [223] and Alzheimer's disease [224]. The method for the efficacy of lithium is unknown.

\section{Pollution/Smog}

A positive association between residential levels of air pollution and a diagnosis of dementia remain even after adjusting for known confounding factors [225]. In a review, many studies show that such ambient environmental exposures present modest-sized risks, but because they are chronic and affect large populations, they affect a large number of cases [226]. 


\section{Medication}

Many medicines can cause cognitive impairment, especially in elderly patients. The BEERS criteria have a detailed and annually updated report on medications and their side effects for older adults. In a 2015, the National Academy of Medicine describes medications (some over the counter) that affect older adults' cognition including antihistamines, antianxiety, antidepressant, sleep aids, antipsychotics, muscle relaxants, antimuscarinics for urinary incontinence, and antispasmodics for relief of cramps or spasms of the stomach, intestines, and bladder [227]. The prevalence of medicationinduced cognitive impairment ranges from 30-80 percent [228]. Older adults are more prone than younger adults, especially those with histories of major mental illness, multiple medication use, and substance abuse who may have one of the highest rates of medication-induced cognitive impairment [229]. The long-term effects of many medications are unknown. Clinical trials tend to overstate benefits and understate deaths [230], and clinical trials tend not to represent older adults, frail and moribund older adults.

\section{DISCUSSION}

In addition to the many studies cited in this review, many other studies exist that are less distinct than the ones presented. Also missing are emerging studies showing how psychological factors promote dementia. The studies collated under this review present a foundation for a serious discussion about the concept-how we think of-and construct - how we measure-dementia.

Despite the unrelenting publications of clinical evidence showing the diversity of potential causes (triggers, promotors, preparers) of dementia and $\mathrm{AD}$, the nearly exclusive focus remains on plaques and tangles. According to the latest Framework [2], these plaques and tangles grow until they interfere with the normal functioning of the brain. The problem is that this assertion is not supported by empirical evidence [6-8]. The evidence contradicts this emphasis of plaques and tangles and supports the contention that this diversion is more political than scientific [7]. As the evidence presented here has demonstrated, many factors contribute, cause, promote or mediate dementias. Many common infections in the elderly such as pneumonia or sepsis can precipitate cognitive decline that continues after adequately treating the infection. It seems that there is indeed a cascading event but not caused by only one trigger. What remains perplexing is why the result of all these activities results in dementia. It is unlikely that dementia is one disease. As found with genetic studies where specific genes were found to affect specific behaviors-behaviors that in sum makeup dementia-we need to separate the disease into its many components.

Various trauma, metabolic syndrome, vascular, fungi, bacteria can impact the brain and produce physical alterations expressed as dementia and AD. Environmental and genetic factors affect the occurrence of fungal and bacterial colonization, while also influencing individual resilience, behavior, and response to disease. All of these factors interact in response to our immune system. With diminished resilience-primarily age-related exacerbated through ill health-such traumas overwhelm the immune system. This diminished resilience refers to senescence as defined by Alex Comfort "... is an adverse change in the living organism, which is loosely correlated with the passage of time, and which leads ultimately to the death of the organism.... a force of mortality" [231; p285]. Later defined as cytogerontology or cell aging Hayflick defines it as “...physiological decrements that lead to cell death..." [232; p54).

More recent research has focused on how inflammation promotes pathology that leads to AD. Specifically intercellular communication mediated by cytokines by which cells of the immune system talk to each other has emerged as a major contributor to the development of $\mathrm{AD}$ [233]. In particular, tumor necrosis factor $\alpha(\mathrm{TNF}-\alpha)$ is looked at as a culprit especially since it is significantly elevated in blood and central nervous system of patients with AD [234]. The body has a method for killing itself.

In contrast, the interconnectedness of different causal elements might provide a better understanding of the genesis and development of dementia and AD. For example, because plaques $(\mathrm{A} \beta)$ are antimicrobial for the fungi $C$. albicans, emerging theories posit that plaques are likely protecting against fungal infection in the brain [235]. The complexity of the brain offers other tantalizing correlates of dementia and $\mathrm{AD}$ in addition to plaques and tangles. The proliferation of both corpora amylacea and corpora arenacea found in great numbers in the brains of patients with neurological diseases including dementia and $\mathrm{AD}$, provide similar correlates with plaques and tangles and yet do not attract the same causal interest despite sharing similar occurrences. Chitinase activity - an enzyme that indicates fungal infectiondetected in cerebrospinal fluid is a better biomarker for $\mathrm{AD}$ with an accuracy of 86 percent that is higher than 78 percent accuracy found for plaques and tangles for AD [236]. All of these observations have emerged organically, not through the efforts of the U.S. NIH's Guidelines and Framework for AD $[1,2]$. Basic science, observant clinical work, and refutable theoretical analyses will be the engine that will eventually bring clarity and later solutions to dementia and $\mathrm{AD}$.

\section{CONCLUSION}

With hundreds of possible causes of dementia, we have to step back and take a broader macro view. All these attacks on our brain happen every day, continuously. We also have to acknowledge that there are interactions between these many causes, they might act sequentially with one cause providing optimal conditions for its successor. The process might also involve a cascading of events, where one insult results in the degradation of a protective feature of the brain allowing for other insults to invade the brain. A complex system trips up. Because the brain is at the center of all activities, receiving the most nutrients through blood, any insult the body receives will eventually find itself in the brain. Having a complex brain ensures that such slight insults are absorbed without any observable deficit, but there might be an accumulation of deficits. Bodo Parady suggests that the abundance of fungal infection is thought to have an evolutionary advantage: "Like a Trojan horse, fungi defeat the innate immune system by hiding inside neural cells." [166, p.146].

Age-related cognitive impairment is not exclusively a human attribute and has been observed in older animals such as primates [237] rodents [238] dogs and cats [239]. AD is an inevitable manifestation of senescence in long-lived animals 
[240]. There might even be support for this evolutionary theory from genetics. The best gene candidate for dementia is the APOE e4 allele. APOE e4 that is implicated in the production of amyloid-beta, might also have had an evolutionary advantage (polymorphism). In the body, amyloid-beta functions as antimicrobial and is present in most animals [241]. Besides, the allele APOE e4 provides protection against hepatitis c liver damage [242] cardiovascular stress [243] miscarriage [244] age-related macule degeneration [245] and protection against malaria [246]. While APOEe4 has antagonistic consequences, including contributing to dementia and diminished intellectual functioning throughout life [247] possibly through increased cholesterol, microhemorrhages, and increased amyloid and tangles [248]. It is only now because we are living longer, in part thanks to APOE e4, that the allele has been classified as detrimental with few centenarians having the alleles. APOE e4 is an ancestral gene that seems to be declining in the gene pool as societies get older [248]. In contrast in evolutionary terms, both APOE e 2 and APOE e3 are newer genes. APOE e2 has been classified as protective and APOE e 3 as neutral. APOE e 3 confers an advantage to modern meat eaters as it protects against cholesterol.

This evolutionary analysis suggests that causes of dementia involve a trade-off. Since the brain is complex it can take a lot of insults before it starts to diminish. All insults, from cranial, cardiovascular, hormone, viral, bacterial, fungi, parasites, misfolded protein, genetics, behavior, environmental and medication affect the brain. The brain sequesters this trauma for the short-term, but with increasing longevity, this tactic has become a long-term liability. Our evolution has endowed humans with a large complex brain with the capacity to isolate infections. We are engineered to sequester these insults until a tipping point is reached, accelerating the senescence of other neurons and glial cells. This tipping point is the disease and not the cause. We are engineered to imitate this senescence across a complex system that is our brain. The speed of injury, severity, location or diminished resilience, all control the speed of diminishment, but once a tipping point is reached the disease takes an accelerated progression independent of its cause. Intervention must therefore include a public health approach while focusing on a small part of this complexity (i.e., plaques and tangles) is knowingly designed for clinical (but not pharmaceutical) failure.

\section{REFERENCES}

[1] Jack CR, Bennett DA, Blennow K, Carrillo MC, Dunn B, Elliott CL, Haeberlein SB, Holtzman DM, Jagust WJ, Jessen F, Karlawish J. 2017 NIA-AA research framework to investigate the Alzheimer's disease continuum. Alzheimer's \& Dementia: The Journal of the Alzheimer's Association. 2017 Jul 1;13(7):P890-1.

[2] Jack Jr CR, Albert MS, Knopman DS, McKhann GM, Sperling RA, Carrillo MC, Thies B, Phelps $\mathrm{CH}$. Introduction to the recommendations from the National Institute on Aging-Alzheimer's Association workgroups on diagnostic guidelines for Alzheimer's disease. Alzheimer's \& Dementia. 2011 May 1;7(3):257-62.

[3] Hardy, J. A. \& Higgins, G. A. Alzheimer's disease: the amyloid cascade hypothesis. Science 256, 184-185 (1992).

[4] Gupta S, Fiertag O, Warner J. Rare and unusual dementias. Advances in psychiatric treatment. 2009 Sep;15(5):364-71

[5] Alzheimers Europe. Rare forms of Dementia General Introduction, Final report of a project supported by the Community Rare Diseases Programme2000-2002. https://ec.europa.eu/health/archive/ph threats/non com/docs/raredem entias_en.pdf

[6] Garrett MD, \& Valle R A. New Public Health Paradigm for Alzheimer's Disease Research. SOJ Neurol. 2015 2(1), 1-9.

[7] Garrett MD. Politics of Anguish: How Alzheimer's disease become the malady of the 21 st century. Createspace. USA.2015

[8] Garrett MD \&Valle RJ.A Methodological Critique of The National Institute of Aging and Alzheimer's Association Guidelines for Alzheimer's disease, Dementia and Mild Cognitive Impairment. Dementia: The International Journal of Social Research and Practice. 2016. 15(2) 239-254

[9] Hayflick L. Theories of biological aging. Experimental gerontology. 1985 Jan 1;20(3-4):145-59.

[10] De Bruijn RFAG, Ikram MA. Cardiovascular risk factors and future risk of Alzheimer's disease. BMC Med 2014; 12: 130.

[11] Zlokovic BV. Neurovascular pathways to neurodegeneration in Alzheimer's disease and other disorders. Nature Reviews Neuroscience. $2011 \mathrm{Dec} ; 12(12): 723$

[12] Sweeney MD, Sagare AP, Zlokovic BV. Blood-brain barrier breakdown in Alzheimer disease and other neurodegenerative disorders. Nature Reviews Neurology. 2018 Mar;14(3):133.

[13] Brundel M, Heringa SM, de Bresser J, Koek HL, Zwanenburg JJ, Kappelle LJ, Luijten PR, Biessels GJ. High prevalence of cerebral microbleeds at 7Tesla MRI in patients with early Alzheimer's disease. Journal of Alzheimer's Disease. 2012 Jan 1;31(2):259-63.

[14] Heringa SM, Reijmer YD, Leemans A, Koek HL, Kappelle LJ, Biessels GJ. Multiple microbleeds are related to cerebral network disruptions in patients with early Alzheimer's disease. Journal of Alzheimer's Disease. 2014 Jan 1;38(1):211-21.

[15] Shams S, Wahlund LO. Cerebral microbleeds as a biomarker in Alzheimer's disease? A review in the field. Biomarkers in medicine. 2016 Jan; $10(1): 9-18$

[16] van der Vlies AE, Goos JD, Barkhof F, Scheltens P, van der Flier WM. Microbleeds do not affect rate of cognitive decline in Alzheimer disease. Neurology. 2012 Aug 21;79(8):763-9.

[17] Wardlaw JM, Makin SJ, Hernández MC, Armitage PA, Heye AK, Chappell FM, Munoz-Maniega S, Sakka E, Shuler K, Dennis MS, Thrippleton MJ. Blood-brain barrier failure as a core mechanism in cerebral small vessel disease and dementia: evidence from a cohort study. Alzheimer's \& Dementia. 2017 Jun 1;13(6):634-43

[18] Nelson AR, Sweeney MD, Sagare AP, Zlokovic BV. Neurovascular dysfunction and neurodegeneration in dementia and Alzheimer's disease. Biochimica et Biophysica Acta (BBA)-Molecular Basis of Disease. 2016 May 1;1862(5):887-900.

[19] Van Gijn J. Leukoaraiosis and vascular dementia. Neurology. 1998 Sep 1;51(3 Suppl 3):S3-8.

[20] Jaraj D, Wikkelsø C, Rabiei K, Marlow T, Jensen C, Östling S, Skoog I. Mortality and risk of dementia in normal-pressure hydrocephalus: A population study. Alzheimer's \& Dementia. 2017 Aug 1;13(8):850-7.

[21] Marmarou A, Young HF, Aygok GA: Estimated incidence of normal pressure hydrocephalus and shunt outcome in patients residing in assisted-living and extended-care facilities. Neurosurg Focus 2007, 22: E1. 5 .

[22] Iseki C, Takahashi Y, Hoshi M, Kimihira L, Ryusuke I, Sato H, Shingo K, Kyoko S, Takeo K. A longitudinal cohort study of idiopathic normal pressure hydrocephalus (iNPH) in the community-dwelling elderly in Takahata, Japan. Journal of the Neurological Sciences. 2017 Oct 15;381:663.

[23] Knopman DS, Petersen RC, Cha RH, et al. : Incidence and causes of nondegenerative nonvascular dementia: a population-based study. Arch Neurol 2006, 63: 218-221

[24] Bech RA, Waldemar G, Gjerris F, et al. Shunting effects in patients with idiopathic normal pressure hydrocephalus: correlation with cerebral and leptomeningeal biopsy findings. Acta Neurochir (Wien) 1999; 141: 633-639.

[25] Golomb J, Wisoff J, Miller DC, et al. Alzheimer's disease comorbidity in normal pressure hydrocephalus: prevalence and shunt response. $\mathbf{J}$ Neurol Neurosurg Psychiatry 2000; 68: 778-781.

[26] Malek-Ahmadi M, Kahlon V, Adler CH, Obradov A, Thind K, Shill HA, Sue LI, Caviness JN, Jacobson S, Sabbagh MN. Prevalence of hippocampal sclerosis in a clinicopathologically characterized cohort. Clinical and Experimental Medical Sciences. 2013;1(7):317.

[27] Josephs KA, Dickson DW, Tosakulwong N, Weigand SD, Murray ME Petrucelli L, Liesinger AM, Senjem ML, Spychalla AJ, Knopman DS, Parisi JE. Rates of hippocampal atrophy and presence of post-mortem TDP-43 in patients with Alzheimer's disease: a longitudinal retrospective study. The Lancet Neurology. 2017 Nov 1;16(11):91724.

[28] Nho K, Saykin AJ, Nelson PT. Hippocampal sclerosis of aging, a common Alzheimer's disease 'mimic': risk genotypes are associated 
with brain atrophy outside the temporal lobe. Journal of Alzheimer's Disease. 2016 Jan 1;52(1):373-83.

[29] Nelson PT, Dickson DW, Trojanowski JQ, Jack CR, Boyle PA, Arfanakis K, Rademakers R, Alafuzoff I, Attems J, Brayne C, CoyleGilchrist IT. Limbic-predominant age-related TDP-43 encephalopathy (LATE): consensus working group report. Brain. 2019 Apr 30;142(6):1503-27.

[30] Calsolaro V, Edison P. Neuroinflammation in Alzheimer's disease: current evidence and future directions. Alzheimer's \& Dementia. 2016 Jun 1;12(6):719-32.

[31] Heneka MT, Carson MJ, El Khoury J, Landreth GE, Brosseron F, Feinstein DL, Jacobs AH, Wyss-Coray T, Vitorica J, Ransohoff RM, Herrup K. Neuroinflammation in Alzheimer's disease. The Lancet Neurology. 2015 Apr 1;14(4):388-405

[32] Purves D, Augustine GJ, Fitzpatrick D, et al., editors. Neuroscience. 2nd edition.

[33] Prins ND, Scheltens P. White matter hyperintensities, cognitive impairment and dementia: an update. Nature Reviews Neurology. 2015 Mar;11(3):157.

[34] Wardlaw JM, Smith EE, Biessels GJ, Cordonnier C, Fazekas F, Frayne R, Lindley RI, T O'Brien J, Barkhof F, Benavente OR, Black SE. Neuroimaging standards for research into small vessel disease and its contribution to ageing and neurodegeneration. The Lancet Neurology. 2013 Aug 1;12(8):822-38.

[35] Esiri, M. M. (2000). Which vascular lesions are of importance in vascular dementia?. Annals of the New York Academy of Sciences, 903(1), 239-243

[36] Elahi FM, Marx G, Cobigo Y, Staffaroni AM, Kornak J, Tosun D, Boxer AL, Kramer JH, Miller BL, Rosen HJ. Longitudinal white matter change in frontotemporal dementia subtypes and sporadic late onset Alzheimer's disease. NeuroImage: Clinical. 2017 Jan 1;16:595-603.

[37] Bejanin A, Desgranges B, La Joie R, Landeau B, Perrotin A, Mézenge F, Belliard S, de La Sayette V, Eustache F, Chételat G. Distinct white matter injury associated with medial temporal lobe atrophy in Alzheimer's versus semantic dementia. Human brain mapping. 2017 Apr;38(4):1791-800.

[38] Veldhuis JD. Changes in pituitary function with ageing and implications for patient care. Nat Rev Endocrinol. 2013 Apr; 9(4):20515

[39] Faul M, Wald MM, Xu L, Coronado VG. Traumatic brain injury in the United States; emergency department visits, hospitalizations, and deaths, 2002-2006.

[40] Szczygielski J, Mautes A, Steudel WI, Falkai P, Bayer TA, Wirths O. Traumatic brain injury: cause or risk of Alzheimer's disease? A review of experimental studies. Journal of neural transmission. 2005 Nov $1 ; 112(11): 1547-64$

[41] Lye TC, Shores EA. Traumatic brain injury as a risk factor for Alzheimer's disease: a review. Neuropsychology review. 2000 Jun $1 ; 10(2): 115-29$.

[42] Fehr SD, Nelson LD, Scharer KR, Traudt EA, Veenstra JM, Tarima SS, Liu XC, Walter KD. Risk factors for prolonged symptoms of mild traumatic brain injury: a pediatric sports concussion clinic cohort. Clinical journal of sport medicine. 2019 Jan 1;29(1):11-7.

[43] Williams H, Caplan B, Bogner J, Brenner L, Cuthbert JP, HarrisonFelix C, Corrigan JD, Kreider S, Bell JM, Coronado VG, Whiteneck GG. Epidemiology of adults receiving acute inpatient rehabilitation for a primary diagnosis of traumatic brain injury in the United States. Journal of head trauma rehabilitation. 2015 Mar 1;30(2):122-35.

[44] Schwab K, Terrio HP, Brenner LA, Pazdan RM, McMillan HP, MacDonald M, Hinds SR, Scher AI. Epidemiology and prognosis of mild traumatic brain injury in returning soldiers: a cohort study. Neurology. 2017 Apr 18;88(16):1571-9.

[45] Ramlackhansingh AF, Brooks DJ, Greenwood RJ, Bose SK, Turkheimer FE, Kinnunen KM, Gentleman S, Heckemann RA, Gunanayagam K, Gelosa G, Sharp DJ. Inflammation after trauma: microglial activation and traumatic brain injury. Annals of neurology. 2011 Sep;70(3):374-83.

[46] Jourdan C, Azouvi P, Genêt F, Selly N, Josseran L, Schnitzler A. Disability and health consequences of traumatic brain injury: national prevalence. American journal of physical medicine \& rehabilitation. 2018 May 1;97(5):323-31.

[47] Li Y, Li Y, Li X, Zhang S, Zhao J, Zhu X, Tian G. Head injury as a risk factor for dementia and Alzheimer's disease: a systematic review and meta-analysis of 32 observational studies. PloS one. 2017 Jan 9;12(1):e0169650

[48] LoBue C, Wilmoth K, Cullum CM, Rossetti HC, Lacritz LH, Hynan LS, Hart J, Womack KB. Traumatic brain injury history is associated with earlier age of onset of frontotemporal dementia. J Neurol Neurosurg Psychiatry. 2016 Aug 1;87(8):817-20.
[49] Sivanandam TM, Thakur MK. Traumatic brain injury: a risk factor for Alzheimer's disease. Neuroscience \& Biobehavioral Reviews. 2012 May 1;36(5):1376-81.

[50] Roberts GW, Allsop D, Bruton C (1990) The occult aftermath of boxing. J Neurol Neurosurg Psychiatry 53: 373-378

[51] Jay CA, Ho EL, Halperin J. Infectious causes of dementia. NonAlzheimer's and Atypical Dementia. 2016 Feb 8:170.

[52] Haji S. Outcome of Tuberculous Meningitis in Adults. Journal of Liaquat University of Medical \& Health Sciences. 2019 Apr 10;18(01):28-33. Haji S. Outcome of Tuberculous Meningitis in Adults. Journal of Liaquat University of Medical \& Health Sciences. 2019 Apr 10;18(01):28-33

[53] Zipser CM, Deuel J, Ernst J, Schubert M, Weller M, von Känel R, Boettger S. Predisposing and precipitating factors for delirium in neurology: a prospective cohort study of 1487 patients. Journal of neurology. 2019 Sep 13:1-1

[54] Bijlsma MW, Brouwer MC, Kasanmoentalib ES, Kloek AT, Lucas MJ, Tanck MW, et al. Community-acquired bacterial meningitis in adults in the Netherlands, 2006-14: a prospective cohort study. Lancet Infect Dis $2016 ; 16$ : $339-47$

[55] Martinez-Vega R, Jauneikaite E, Thoon KC, Chua HY, Chua AH, Khong WX, Tan BH, Hong JL, Venkatachalam I, Tambyah PA, Hibberd ML. Risk factor profiles and clinical outcomes for children and adults with pneumococcal infections in Singapore: A need to expand vaccination policy?. PloS one. 2019;14(10).

[56] T O'Brien J, Thomas A. Vascular dementia. The Lancet. 2015 Oct 24;386(10004):1698-706.

[57] de la Torre JC: Cardiovascular risk factors promote brain hypoperfusion leading to cognitive decline and dementia. Cardiovasc Psychiatry Neurol. 2012, 2012: 367516.

[58] Goldberg I, Auriel E, Russell D, Korczyn AD: Microembolism, silent brain infarcts and dementia. J Neurol Sci. 2012, 322: 250-253.

[59] Qiu C, Winblad B, Marengoni A, Klarin I, Fastbom J, Fratiglioni L: Heart failure and risk of dementia and Alzheimer disease: a populationbased cohort study. Arch Intern Med. 2006, 166: 1003-1008.

[60] Jefferson AL, Himali JJ, Beiser AS, Au R, Massaro JM, Seshadri S, Gona P, Salton CJ, DeCarli C, O'Donnell CJ, Benjamin EJ, Wolf PA, Manning WJ: Cardiac index is associated with brain aging: the Framingham Heart Study. Circulation. 2010, 122: 690-697.

[61] Raz L, Knoefel J, Bhaskar K. The neuropathology and cerebrovascular mechanisms of dementia. Journal of Cerebral Blood Flow \& Metabolism. 2016 Jan;36(1):172-86.

[62] de Bruijn RF, Ikram MA. Cardiovascular risk factors and future risk of Alzheimer's disease. BMC medicine. 2014 Dec;12(1):130.

[63] Arvanitakis Z, Capuano AW, Leurgans SE, Bennett DA, Schneider JA. Relation of cerebral vessel disease to Alzheimer's disease dementia and cognitive function in elderly people: a cross-sectional study. The Lancet Neurology. 2016 Aug 1;15(9):934-43.

[64] Iturria-Medina Y, Sotero RC, Toussaint PJ, Mateos-Pérez JM, Evans AC, Weiner MW, Aisen P, Petersen R, Jack CR, Jagust W, Trojanowki JQ. Early role of vascular dysregulation on late-onset Alzheimer's disease based on multifactorial data-driven analysis. Nature communications. 2016 Jun 21;7:11934.

[65] Faraco G, Park L, Zhou P, Luo W, Paul SM, Anrather J, Iadecola C. Hypertension enhances A $\beta$-induced neurovascular dysfunction, promotes $\beta$-secretase activity, and leads to amyloidogenic processing of APP. Journal of Cerebral Blood Flow \& Metabolism. 2016 Jan;36(1):241-52.

[66] Wardlaw JM, Valdés Hernández MC, Muñoz-Maniega S. What are white matter hyperintensities made of? Relevance to vascular cognitive impairment. Journal of the American Heart Association. 2015 Jun 23;4(6):e001140.

[67] Snyder HM, Corriveau RA, Craft S, Faber JE, Greenberg SM, Knopman D, Lamb BT, Montine TJ, Nedergaard M, Schaffer CB, Schneider JA. Vascular contributions to cognitive impairment and dementia including Alzheimer's disease. Alzheimer's \& Dementia. 2015 Jun 1;11(6):710-7.

[68] Hachinski V. Stroke and potentially preventable dementias proclamation: updated World Stroke Day Proclamation.

[69] Justin BN, Turek M, Hakim AM: Heart disease as a risk factor for dementia. Clin Epidemiol. 2013, 5: 135-145.

[70] Muqtadar H, Testai FD, Gorelick PB: The dementia of cardiac disease. Curr Cardiol Rep. 2012, 14: 732-740.

[71] Duron E, Hanon O: Vascular risk factors, cognitive decline, and dementia. Vasc Health Risk Manag. 2008, 4: 363-381.

[72] Pinkston JB, Alekseeva N, González Toledo E. Stroke and dementia Neurological research. 2009 Oct 1;31(8):824-31.

[73] Mijajlović MD, Pavlović A, Brainin M, Heiss WD, Quinn TJ, IhleHansen HB, Hermann DM, Assayag EB, Richard E, Thiel A, Kliper E. 
Post-stroke dementia-a comprehensive review. Bmc Medicine. 2017 Dec;15(1):1-2

[74] Ivan CS, Seshadri S, Beiser A, Au R, Kase CS, Kelly-Hayes M, Wolf PA. Dementia after stroke: the Framingham Study. Stroke. 2004 Jun $1 ; 35(6): 1264-8$.

[75] Lim, J. S. (2020). Post-stroke Cognitive Impairment. In Stroke Revisited: Vascular Cognitive Impairment (pp. 15-24). Springer, Singapore.

[76] Matz, K., Teuschl, Y., Firlinger, B., Dachenhausen, A., Keindl, M., Seyfang, L., ... \& Bancher, C. (2015). Multidomain lifestyle interventions for the prevention of cognitive decline after ischemic stroke: randomized trial. Stroke, 46(10), 2874-2880.

[77] Ankolekar, S., \& Simoni, M. (2020). Post-stroke cognitive impairment. Stroke in the Older Person, 28(3), 381.

[78] Teasell, R., Bayona, N. A., \& Bitensky, J. (2005). Plasticity and reorganization of the brain post stroke. Topics in stroke rehabilitation, 12(3), 11-26.

[79] Kwok CS, Loke YK, Hale R, Potter JF, Myint PK: Atrial fibrillation and incidence of dementia: a systematic review and meta-analysis. Neurology. 2011, 76: 914-922.

[80] Troncoso JC, Zonderman AB, Resnick SM, Crain B, Pletnikova O, O'Brien RJ: Effect of infarcts on dementia in the Baltimore longitudinal study of aging. Ann Neurol. 2008, 64: 168-176

[81] Vermeer SE, Prins ND, den Heijer T, Hofman A, Koudstaal PJ, Breteler MM: Silent brain infarcts and the risk of dementia and cognitive decline. N Engl J Med. 2003, 348: 1215-1222.

[82] Arvanitakis Z, et al. Microinfarct pathology, dementia, and cognitive systems. Stroke. 2011;42(3):722-727.

[83] Purandare N, et al. Association of cerebral emboli with accelerated cognitive deterioration in Alzheimer's disease and vascular dementia. Am J Psychiatry. 2012;169(3):300-308.

[84] Lewington S, Clarke R, Qizilbash N, Peto R, Collins R. Age-specific relevance of usual blood pressure to vascular mortality: a meta-analysis of individual data for one million adults in 61 prospective studies. Lancet. 2002;360(9349):1903-13.

[85] Center for Disease Control and Prevention; NHANES Examination Data; Blood Pressure in 2013-2014. Accessed: https://wwwn.cdc.gov/nchs/nhanes/Search/DataPage.aspx?Componen $\mathrm{t}=$ Examination for $\mathrm{BP}$ data.

[86] Anker D, Santos-Eggimann B, Santschi V, Del Giovane C, Wolfson C, Streit S, Rodondi N, Chiolero A. Screening and treatment of hypertension in older adults: less is more?. Public health reviews. 2018 Dec;39(1):1-6.

[87] Eurostat. Cardiovascular disease statistics. Available from http://ec.europa.eu/eurostat/statisticsexplained/index.php/Cardiovascular_diseases_statistics. Accessed 30.08.2017.

[88] Yoon SS, Fryar CD, Carroll MD. Hypertension prevalence and control among adults: United States, 2011-2014. NCHS data brief, no 220 Hyattsville, MD: National Center for Health Statistics; 2015.

[89] Whitmer RA, Sidney S, Selby J, Johnston SC, Yaffe K: Midlife cardiovascular risk factors and risk of dementia in late life. Neurology. 2005, 64: 277-281

[90] Joas E, Backman K, Gustafson D, Ostling S, Waern M, Guo X, Skoog I: Blood pressure trajectories from midlife to late life in relation to dementia in women followed for 37 years. Hypertension. 2012, 59: 796-801.

[91] Qiu C, Winblad B, Fratiglioni L: The age-dependent relation of blood pressure to cognitive function and dementia. Lancet Neurol. 2005, 4 487-499.

[92] Bos D, Vernooij MW, de Bruijn RF, Koudstaal PJ, Hofman A, Franco $\mathrm{OH}$, van der Lugt A, Ikram MA. Atherosclerotic calcification is related to a higher risk of dementia and cognitive decline. Alzheimer's \& Dementia. 2015 Jun 1;11(6):639-47.

[93] Javanshiri K, Waldö ML, Friberg N, Sjövall F, Wickerström K, Haglund M, Englund E. Atherosclerosis, hypertension, and diabetes in Alzheimer's disease, vascular dementia, and mixed dementia: prevalence and presentation. Journal of Alzheimer's Disease. 2018 Jan $1 ; 65(4): 1247-58$

[94] Ross R. Atherosclerosis - an inflammatory disease. New England journal of medicine. 1999 Jan 14;340(2):115-26.

[95] Biessels GJ, Staekenborg S, Brunner E, Brayne C, Scheltens P. Risk of dementia in diabetes mellitus: a systematic review. The Lancet Neurology. 2006 Jan 1;5(1):64-74.

[96] Pal, K., Mukadam, N., Petersen, I., \& Cooper, C. (2018). Mild cognitive impairment and progression to dementia in people with diabetes, prediabetes and metabolic syndrome: a systematic review and meta-analysis. Social psychiatry and psychiatric epidemiology, 53(11), 1149-1160.
[97] Atti, A. R., Valente, S., Iodice, A., Caramella, I., Ferrari, B., Albert, U., ... \& De Ronchi, D. (2019). Metabolic Syndrome (MetS), Mild Cognitive Impairment (MCI) and Dementia: a meta-analysis of longitudinal studies. The American Journal of Geriatric Psychiatry.

[98] Tortelli, R., Lozupone, M., Guerra, V., Barulli, M. R., Imbimbo, B. P., Capozzo, R., ... \& Giannelli, G. (2017). Midlife metabolic profile and the risk of late-life cognitive decline. Journal of Alzheimer's Disease, 59(1), 121-130.

[99] Yokomichi, H., Kondo, K., Nagamine, Y., Yamagata, Z., \& Kondo, N. (2020). Dementia risk by combinations of metabolic diseases and body mass index: Japan Gerontological Evaluation Study Cohort Study. Journal of Diabetes Investigation, 11(1), 206-215.

[100] Schmidt R, Launer LJ, Nilsson LG, Pajak A, Sans S, Berger K, Breteler MM, de Ridder M, Dufouil C, Fuhrer R, Giampaoli S, Hofman A, Consortium $\mathrm{C}$ : Magnetic resonance imaging of the brain in diabetes: the Cardiovascular Determinants of Dementia (CASCADE) Study. Diabetes. 2004, 53: 687-692.

[101]Peila R, Rodriguez BL, Launer LJ, Honolulu-Asia Aging S: Type 2 diabetes, APOE gene, and the risk for dementia and related pathologies: the Honolulu-Asia Aging Study. Diabetes. 2002, 51: 12561262.Biessels GJ, Staekenborg S, Brunner E, Brayne C, Scheltens P Risk of dementia in diabetes mellitus: a systematic review. Lancet Neurol. 2006, 5: 64-74.

[102] Ahmad MH, Fatima M, Mondal AC. Role of Hypothalamic-PituitaryAdrenal Axis, Hypothalamic-Pituitary-Gonadal Axis and Insulin Signaling in the Pathophysiology of Alzheimer's Disease. Neuropsychobiology. 2019;77(4):197-205.

[103]Kandasamy M, Radhakrishnan RK, Abirami GP, Roshan SA, Yesudhas A, Balamuthu K, Prahalathan C, Shanmugaapriya S, Moorthy A, Essa MM, Anusuyadevi M. Possible Existence of the Hypothalamic-Pituitary-Hippocampal (HPH) Axis: A Reciprocal Relationship Between Hippocampal Specific Neuroestradiol Synthesis and Neuroblastosis in Ageing Brains with Special Reference to Menopause and Neurocognitive Disorders. Neurochemical research. 2019 Jun 28:1-5

[104]Copinschi G, Caufriez A. Sleep and hormonal changes in aging. Endocrinology and Metabolism Clinics. 2013 Jun 1;42(2):371-89.

[105] Ouanes S, Popp J. High cortisol and the risk of dementia and Alzheimer's disease: a review of the literature. Frontiers in Aging Neuroscience. 2019;11.

[106]Ferrari E, Arcaini A, Gornati R, Pelanconi L, Cravello L, Fioravanti M, Solerte SB, Magri F. Pineal and pituitary-adrenocortical function in physiological aging and in senile dementia. Experimental gerontology. 2000 Dec 1;35(9-10):1239-50.

[107] Gottfries CG, Balldin J, Blennow K, Bråne GÖ, Karlsson I, Regland B, Wallin A. Regulation of the hypothalamic-pituitary-adrenal axis in dementia disorders. Annals of the New York Academy of Sciences. 1994 Nov;746:336-43.

[108] McCurry SM, Logsdon RG, Teri L et al. Characteristics of sleep disturbance in community-dwelling Alzheimer's disease patients. J Geriatr Psychiatry Neurol 1999; 12: 53-59.

[109] Vitiello MV, Borson S. Sleep disturbances in patients with Alzheimer's disease: epidemiology, pathophysiology and treatment. CNS Drugs 2001; 15: 777-796.

[110]Guarnieri B, Adorni F, Musicco M et al. Prevalence of sleep disturbances in mild cognitive impairment and dementing disorders: a multicenter Italian clinical cross-sectional study on 431 patients. Dement Geriatr Cogn Disord 2012; 33: 50-58.

[111] Ohashi Y, Okamoto N, Uchida K et al. Daily rhythm of serum melatonin levels and effect of light exposure in patients with dementia of the Alzheimer's type. Biol Psychiatry 1999; 451: 1646- 1652.

[112] Swaab DF, Fliers E, Partiman TS. The suprachiasmatic nucleus of the human brain in relation to sex, age and senile dementia. Brain Res 1985; 342: 37- 44

[113] Gupta P, Sethi PK, Anand I, Batra A, Patel S, Rana DS. Thalamic Dementia with Stroke: A short case series. AJCNN. 2015;1(2):99-101.

[114]Bocchetta M, Gordon E, Cardoso MJ, Modat M, Ourselin S, Warren JD, Rohrer JD. Thalamic atrophy in frontotemporal dementia-Not just a C9orf72 problem. NeuroImage: Clinical. 2018 Jan 1;18:675-81.

[115] Dugbartey AT. Neurocognitive aspects of hypothyroidism. Arch Intern Med. 1998;158:1413-1418.

[116]Tan ZS, Vasan RS: Thyroid function and Alzheimer's disease. J Alzheimers Dis. 2009, 16: 503-507.

[117]Haggerty JJ, Evans DL, Prange AT. Organic brain syndrome associated with marginal hypothyroidism. Am J Psychiatry. 1986;143:785-786.

[118]Clarnette RM, Patterson CJ. Hypothyroidism: does treatment cure dementia? J Geriatr Psychiatry Neurol. 1994;7:23-27.

[119] de Jong FJ, Masaki K, Chen H, Remaley AT, Breteler MM, Petrovitch $\mathrm{H}$, White LR, Launer LJ: Thyroid function, the risk of dementia and 
neuropathologic changes: the Honolulu-Asia aging study. Neurobiol Aging. 2009, 30: 600-606.

[120]Kalmijn S, Mehta KM, Pols HA, Hofman A, Drexhage HA, Breteler MM: Subclinical hyperthyroidism and the risk of dementia, the Rotterdam study. Clin Endocrinol (Oxf). 2000, 53: 733-737

[121]Marx J. Fresh evidence points to an old suspect: calcium.

[122] Goto S, Hirano A, Matsumoto S. Immunohistochemical study of the striatal efferents and nigral dopaminergic neurons in parkinsonismdementia complex on guam in comparison with those in Parkinson's and Alzheimer's diseases. Annals of Neurology: Official Journal of the American Neurological Association and the Child Neurology Society. 1990 May;27(5):520-7.

[123]Furman JL, Norris CM. Calcineurin and glial signaling: neuroinflammation and beyond. Journal of neuroinflammation. 2014 Dec 1;11(1):158.

[124] Taglialatela G, Rastellini C, Cicalese L. Reduced incidence of dementia in solid organ transplant patients treated with calcineurin inhibitors. Journal of Alzheimer's Disease. 2015 Jan 1;47(2):329-33.

[125]Lourida I, Thompson-Coon J, Dickens CM, Soni M, Kuźma E, Kos K Llewellyn DJ. Parathyroid hormone, cognitive function and dementia: a systematic review. PLoS One. 2015 May 26;10(5):e0127574.

[126]Vest RS, Pike CJ. Gender, sex steroid hormones, and Alzheimer's disease. Hormones and behavior. 2013 Feb 1;63(2):301-7.

[127]Cui J, Shen Y, Li R. Estrogen synthesis and signaling pathways during aging: from periphery to brain. Trends in molecular medicine. 2013 Mar 1;19(3):197-209.

[128]Luine VN. Estradiol and cognitive function: past, present and future. Hormones and behavior. 2014 Sep 1;66(4):602-18.

[129] Maki PM, Henderson VW. Hormone therapy, dementia, and cognition the Women's Health Initiative 10 years on. Climacteric. 2012 Jun $1 ; 15(3): 256-62$.

[130]Maki PM, Zonderman AB, Resnick SM. Enhanced verbal memory in nondemented elderly women receiving hormone-replacement therapy. American journal of psychiatry. 2001 Feb 1;158(2):227-33.

[131]Kandasamy M, Radhakrishnan RK, Abirami GP, Roshan SA, Yesudhas A, Balamuthu K, Prahalathan C, Shanmugaapriya S, Moorthy A, Essa MM, Anusuyadevi M. Possible Existence of the Hypothalamic-Pituitary-Hippocampal (HPH) Axis: A Reciprocal Relationship Between Hippocampal Specific Neuroestradiol Synthesis and Neuroblastosis in Ageing Brains with Special Reference to Menopause and Neurocognitive Disorders. Neurochemical research. 2019 Jun 28:1-5

[132] Moffat SD, Zonderman AB, Metter EJ, Kawas C, Blackman MR, Harman SM, Resnick SM. Free testosterone and risk for Alzheimer disease in older men. Neurology. 2004 Jan 27;62(2):188-93

[133] Verdile G, Laws SM, Henley D, Ames D, Bush AI, Ellis KA, Faux NG, Gupta VB, Li Q, Masters CL, Pike KE. Associations between gonadotropins, testosterone and $\beta$ amyloid in men at risk of Alzheimer's disease. Molecular psychiatry. 2014 Jan;19(1):69.

[134]Hogervorst E, Combrinck M, Smith AD. Testosterone and gonadotropin levels in men with dementia. Neuroendocrinology letters. 2003 Jun 1;24(3-4):203-8.

[135]Hall JR, Wiechmann AR, Cunningham RL, Johnson LA, Edwards M, Barber RC, Singh M, Winter S, O'Bryant SE. Total testosterone and neuropsychiatric symptoms in elderly men with Alzheimer's disease. Alzheimer's research \& therapy. 2015 Dec;7(1):24.

[136]Karim S, Mirza Z, A Kamal M, M Abuzenadah A, I Azhar E, H AlQahtani M, A Damanhouri G, Ahmad F, H Gan S, S Sohrab S. The role of viruses in neurodegenerative and neurobehavioral diseases. CNS \& Neurological Disorders-Drug Targets (Formerly Current Drug TargetsCNS \& Neurological Disorders). 2014 Sep 1;13(7):1213-23.

[137]Neuenburg J. The neuropathology of HIV Pre-and Post-HAART. InThe Spectrum of Neuro-AIDS Disorders 2009 Jan 1 (pp. 181-199). American Society of Microbiology.

[138]Tzeng NS, Chung CH, Lin FH, Chiang CP, Yeh CB, Huang SY, Lu RB, Chang HA, Kao YC, Yeh HW, Chiang WS. Anti-herpetic medications and reduced risk of dementia in patients with herpes simplex virus infections - a nationwide, population-based cohort study in Taiwan. Neurotherapeutics. 2018 Apr 1;15(2):417-29.

[139]Ball MJ. Limbic predilection in Alzheimer dementia: is reactivated herpesvirus involved?. Canadian Journal of Neurological Sciences. 1982 Aug;9(3):303-6.

[140]Itzhaki RF, Lin WR, Shang D, Wilcock GK, Faragher B, Jamieson GA Herpes simplex virus type 1 in brain and risk of Alzheimer's disease. The Lancet. 1997 Jan 25;349(9047):241-4.

[141]Balin BJ, Hudson AP. Herpes viruses and Alzheimer's disease: new evidence in the debate. The Lancet Neurology. 2018 Oct 1;17(10):83941.
[142]Lin WR, Wozniak MA, Wilcock GK, Itzhaki RF. Cytomegalovirus is present in a very high proportion of brains from vascular dementia patients. Neurobiology of disease. 2002 Feb 1;9(1):82-7.

[143] Barnes LL, Capuano AW, Aiello AE, Turner AD, Yolken RH, Torrey EF, Bennett DA. Cytomegalovirus infection and risk of Alzheimer disease in older black and white individuals. The Journal of infectious diseases. 2014 Aug 8;211(2):230-7.

[144] Aiello AE, Haan MN, Blythe L, Moore K, Gonzalez JM, Jagust W. The influence of latent viral infection on rate of cognitive decline over 4 years. Journal of the American Geriatrics Society. 2006 Jul;54(7):1046-54

[145] Gow AJ, Firth CM, Harrison R, Starr JM, Moss P, Deary IJ. Cytomegalovirus infection and cognitive abilities in old age. Neurobiology of aging. 2013 Jul 1;34(7):1846-52.

[146] Tarter KD, Simanek AM, Dowd JB, Aiello AE. Persistent viral pathogens and cognitive impairment across the life course in the third national health and nutrition examination survey. The Journal of infectious diseases. 2013 Nov 18;209(6):837-44.

[147] Torniainen-Holm M, Suvisaari J, Lindgren M, Härkänen T, Dickerson F, Yolken RH. Association of cytomegalovirus and Epstein-Barr virus with cognitive functioning and risk of dementia in the general population: 11-year follow-up study. Brain, behavior, and immunity. 2018 Mar 1;69:480-5.

[148] Warren-Gash C, Forbes HJ, Williamson E, Breuer J, Hayward AC, Mavrodaris A, Ridha BH, Rossor MN, Thomas SL, Smeeth L. Human herpesvirus infections and dementia or mild cognitive impairment: a systematic review and meta-analysis. Scientific reports. 2019 Mar 18;9(1):4743.

[149] Steel AJ, Eslick GD. Herpes viruses increase the risk of Alzheimer's disease: a meta-analysis. Journal of Alzheimer's Disease. 2015 Jan 1;47(2):351-64.

[150] Torniainen-Holm M, Suvisaari J, Lindgren M, Härkänen T, Dickerson F, Yolken RH. Association of cytomegalovirus and Epstein-Barr virus with cognitive functioning and risk of dementia in the general population: 11-year follow-up study. Brain, behavior, and immunity. 2018 Mar 1;69:480-5.

[151]Lycke E, Norrby R, Roos BE. A Serological Study on Mentally Ill Patients: With Particular Reference to the Prevalence of Herpes Virus Infections. The British Journal of Psychiatry. 1974 Mar;124(580):2739.

[152]Tsai M-C, Cheng W-L, Sheu J-J, et al., Increased risk of dementia following herpes zoster ophthalmicus. PLoS One. 2017; 12(11):

[153]Perusini G. Histology and clinical findings of some psychiatric diseases of older people. 1910 .

[154]Balin BJ, Gérard HC, Arking EJ, Appelt DM, Branigan PJ, Abrams JT, Whittum-Hudson JA, Hudson AP. Identification and localization of Chlamydia pneumoniae in the Alzheimer's brain. Medical microbiology and immunology. 1998 Aug 1;187(1):23-42.

[155] Schumacher Jr HR, G' erard HE, Arayssi TK, Pando JA, Branigan PJ, Saaibi DL, Hudson AP. Lower prevalence of Chlamydia pneumoniae DNA compared with Chlamydia trachomatis DNA in synovial tissue of arthritis patients. Arthritis \& Rheumatism: Official Journal of the American College of Rheumatology. 1999 Sep;42(9):1889-93.

[156]Balin PhD BJ, Hammond C, Little CS, Hingley S, Appelt D, WhittumHudson JA, Gerard HC, Hudson AP. Chlamydia Pneumoniae as an Etiologic Agent for Late-Onset Alzheimer's Disease.

[157] Pearson S. Recognising and understanding Lyme disease. Nursing Standard. 2014 Sep 3;29(1).

[158]Blanc F, Philippi N, Cretin B, Kleitz C, Berly L, Jung B, Kremer S, Namer IJ, Sellal F, Jaulhac B, de Seze J. Lyme neuroborreliosis and dementia. Journal of Alzheimer's Disease. 2014 Jan 1;41(4):1087-93.

[159]Doulberis M, Kotronis G, Thomann R, Polyzos SA, Boziki M, Gialamprinou D, et al. Impact of Helicobacter pylori on Alzheimer's disease: what do we know so far? Helicobacter 2018;23.

[160]Fani L, Wolters FJ, Ikram MK, Bruno MJ, Hofman A, Koudstaal PJ, Murad SD, Ikram MA. Helicobacter pylori and the risk of dementia: a population-based study. Alzheimer's \& Dementia. 2018 Oct 1;14(10):1377-82

[161]Brown BM, Peiffer JJ, Martins RN. Multiple effects of physical activity on molecular and cognitive signs of brain aging: can exercise slow neurodegeneration and delay Alzheimer's disease? Mol Psychiatry. 2013;18:864-74.

[162]Reyes AJ, Ramcharan K, Perot S, Giddings SL, Rampersad F, Gobin R. Subacute sclerosing panencephalitis causing rapidly progressive dementia and myoclonic jerks in a sexagenarian woman. Tremor and Other Hyperkinetic Movements. 2019;9.

[163] Alonso R, Pisa D, Aguado B, Carrasco L. Identification of fungal species in brain tissue from Alzheimer's disease by next-generation sequencing. Journal of Alzheimer's Disease. 2017 Jan 1;58(1):55-67. 
[164]Di Rosa M, Dell'Ombra N, Zambito AM, Malaguarnera M, Nicoletti F, Malaguarnera L. Chitotriosidase and inflammatory mediator levels in Alzheimer's disease and cerebrovascular dementia. European Journal of Neuroscience. 2006 May;23(10):2648-56.

[165]Alonso R, Pisa D, Fernández-Fernández AM, Carrasco L. Infection of fungi and bacteria in brain tissue from elderly persons and patients with Alzheimer's disease. Frontiers in aging neuroscience. 2018 May 24;10:159.

[166]Parady B. Innate immune and fungal model of Alzheimer's disease. Journal of Alzheimer's disease reports. 2018 Jan 1;2(1):139-52.

[167]Kusbeci OY, Miman O, Yaman M, Aktepe OC, Yazar S. Could Toxoplasma gondii have any role in Alzheimer disease?. Alzheimer Disease \& Associated Disorders. 2011 Jan 1;25(1):1-3.

[168]Bayani M, Riahi SM, Bazrafshan N, Gamble HR, Rostami A Toxoplasma gondii infection and risk of Parkinson and Alzheimer diseases: A systematic review and meta-analysis on observational studies. Acta tropica. 2019 May 15

[169] de Andrade DC, Rodrigues CL, Abraham R, Castro LH, Livramento JA, Machado LR, Leite CC, Caramelli P. Cognitive impairment and dementia in neurocysticercosis: a cross-sectional controlled study. Neurology. 2010 Apr 20;74(16):1288-95.

[170] May M. Translating big data: The proteomics challenge..Science Jun. 14, 2018.

[171]Bloom GS. Amyloid- $\beta$ and tau: the trigger and bullet in Alzheimer disease pathogenesis. JAMA neurology. 2014 Apr 1;71(4):505-8.

[172]Bianconi E, Piovesan A, Facchin F, Beraudi A, Casadei R, Frabetti F, Vitale L, Pelleri MC, Tassani S, Piva F, Perez-Amodio S. An estimation of the number of cells in the human body. Annals of human biology. 2013 Nov 1;40(6):463-71

[173]Iqbal K, Liu F, Gong CX. Alzheimer disease therapeutics: focus on the disease and not just plaques and tangles. Biochemical pharmacology. 2014 Apr 15;88(4):631-9.

[174]Boche D, Donald J, Love S, Harris S, Neal JW, Holmes C, Nicoll JA. Reduction of aggregated Tau in neuronal processes but not in the cell bodies after A 342 immunisation in Alzheimer's disease. Acta neuropathologica. 2010 Jul 1;120(1):13-20.

[175] Gilman S, Koller M, Black RS, Jenkins L, Griffith SG, Fox NC, Eisner L, Kirby L, Rovira MB, Forette F, Orgogozo JM. Clinical effects of A $\beta$ immunization (AN1792) in patients with $\mathrm{AD}$ in an interrupted trial. Neurology. 2005 May 10;64(9):1553-62.

[176] Snowdon DA. Aging and Alzheimer's disease: lessons from the Nun Study. The Gerontologist. 1997 Apr 1;37(2):150-6.

[177] Snowdon DA. Healthy aging and dementia: findings from the Nun Study. Annals of internal medicine. 2003 Sep 2;139(5_Part_2):450-4.

[178] Snowdon DA, Greiner LH, Mortimer JA, et al. Brain infarction and the clinical expression of Alzheimer disease. The Nun Study. JAMA. 1997;277:813-817.

[179]Crystal HA, Dickson D, Davies P, Masur D, Grober E, Lipton RB. The relative frequency of dementia of unknown etiology increases with age and is nearly 50 percent in nonagenarians. Archives of Neurology. 2000 May 1;57(5):713-9.

[180]Polvikoski T, Sulkava R, Myllykangas L, Notkola IL, Niinistö L, Verkkoniemi A, Kainulainen K, Kontula K, Pérez-Tur J, Hardy J, Haltia M. Prevalence of Alzheimer's disease in very elderly people: a prospective neuropathological study. Neurology. 2001 Jun 26;56(12):1690-6.

[181]Crystal H, Dickson D, Fuld P, Masur D, Scott R, Mehler M, Masdeu J, Kawas C, Aronson M, Wolfson L. Clinico-pathologic studies in dementia: nondemented subjects with pathologically confirmed Alzheimer's disease. Neurology. 1988 Nov 1;38(11):1682-.

[182] Katzman R, Terry R, DeTeresa R, Brown T, Davies P, Fuld P, Renbing $\mathrm{X}$, Peck A. Clinical, pathological, and neurochemical changes in dementia: a subgroup with preserved mental status and numerous neocortical plaques. Annals of Neurology: Official Journal of the American Neurological Association and the Child Neurology Society. $1988 \mathrm{Feb} ; 23(2): 138-44$.

[183]Tomlinson BE, Blessed G, Roth M. Observations on the brains of demented old people. Journal of the neurological sciences. 1970 Sep 1;11(3):205-42.

[184] Hammer ND, Wang X, McGuffie BA, Chapman MR. Amyloids: friend or foe?. Journal of Alzheimer's disease. 2008 Jan 1;13(4):407-19.

[185] Kim et al. A draft map of the human proteome. 2014. Nature. 509, 575 581

[186]Jørn N, Hansen D, Hansen NJ. Human spongiform encephalopathies. Diseases caused by prions. Ugeskrift for laeger. 1996 Jul;158(28):4066-72.

[187] van Everbroeck B, Pals P, Quoilin S, MARTIN JJ, Cras P. Invited review The many faces of human prion diseases in Belgium and the world. Acta neurol. belg. 2001;101:81-7.
[188]Campion D, Dumanchin C, Hannequin D, et al. Early-onset autosomal dominant Alzheimer disease: prevalence, genetic heterogeneity, and mutation spectrum. Am J Hum Genet 1999; 65:664-670.

[189] Wu L, Rosa-Neto P, Hsiung GY, Sadovnick AD, Masellis M, Black SE, Jia J, Gauthier S. Early-onset familial Alzheimer's disease (EOFAD). Canadian Journal of Neurological Sciences. 2012 Jul;39(4):436-45.

[190] Shea YF, Chu LW, Chan AO, Ha J, Li Y, Song YQ. A systematic review of familial Alzheimer's disease: Differences in presentation of clinical features among three mutated genes and potential ethnic differences. Journal of the Formosan Medical Association. 2016 Feb $1 ; 115(2): 67-75$.

[191]Ballard C, Mobley W, Hardy J, Williams G, Corbett A. Dementia in Down's syndrome. The Lancet Neurology. 2016 May 1;15(6):622-36.

[192] Visser FE, Aldenkamp AP, Van Huffelen AC, Kuilman M. Prospective study of the prevalence of Alzheimer-type dementia in institutionalized individuals with Down syndrome. American Journal on Mental Retardation. 1997 Jan.

[193]Evenhuis HM. The natural history of dementia in Down's syndrome. Archives of Neurology. 1990 Mar 1;47(3):263-7.

[194]Menéndez M. Down syndrome, Alzheimer's disease and seizures. Brain and Development. 2005 Jun 1;27(4):246-52.

[195]Almond MH, Edwards MR, Barclay WS, Johnston SL. Obesity and susceptibility to severe outcomes following respiratory viral infection. Thorax. 2013;68:684-6

[196]Chidiac C. Pneumococcal infections and adult with risk factors. Med Mal Infect. 2012;42:517-24.

[197] Whitmer RA, Gustafson DR, Barrett-Connor E, Haan MN, Gunderson EP, Yaffe K. Central obesity and increased risk of dementia more than three decades later. Neurology. 2008;71:1057-64.

[198]Le Chatelier E, Nielsen T, Qin J, et al. Richness of human gut microbiome correlates with metabolic markers. Nature. 2013;500:541-

[199]Berlin JA, Colditz GA: A meta-analysis of physical activity in the prevention of coronary heart disease. Am J Epidemiol. 1990, 132: 612628

[200]Blondell SJ, Hammersley-Mather R, Veerman JL. Does physical activity prevent cognitive decline and dementia?: A systematic review and meta-analysis of longitudinal studies. BMC public health. 2014 Dec;14(1):510.

[201]Kuźma E, Llewellyn DJ, Langa KM, Wallace RB, Lang IA. History of alcohol use disorders and risk of severe cognitive impairment: a 19year prospective cohort study. The American Journal of Geriatric Psychiatry. 2014 Oct 1;22(10):1047-54.

[202] Anstey KJ, von Sanden C, Salim A, O'Kearney R: Smoking as a risk factor for dementia and cognitive decline: a meta-analysis of prospective studies. Am J Epidemiol. 2007, 166: 367-378.

[203] Thomas VS, Rockwood KJ. Alcohol abuse, cognitive impairment, and mortality among older people. Journal of the American Geriatrics Society. 2001 Apr;49(4):415-20.

[204]Perreira KM, Sloan FA. Excess alcohol consumption and health outcomes: A 6-year follow-up of men over age 50 from the health and retirement study. Addiction. 2002 Mar;97(3):301-10.

[205]Lopes MA, Ferrioli E, Nakano EY, Litvoc J, Bottino CM. High prevalence of dementia in a community-based survey of older people from Brazil: association with intellectual activity rather than education. Journal of Alzheimer's Disease. 2012 Jan 1;32(2):307-16.

[206]Reitz C, den Heijer T, van Duijn C, Hofman A, Breteler MM: Relation between smoking and risk of dementia and Alzheimer disease: the Rotterdam Study. Neurology. 2007, 69: 998-1005.

[207] Tyas SL, White LR, Petrovitch H, Webster Ross G, Foley DJ, Heimovitz HK, Launer LJ: Mid-life smoking and late-life dementia: the Honolulu-Asia Aging Study. Neurobiol Aging. 2003, 24: 589-596.

[208] Messner B, Bernhard D: Smoking and cardiovascular disease: mechanisms of endothelial dysfunction and early atherogenesis Arterioscler Thromb Vasc Biol. 2014, 34: 509-515.

[209]Deal JA, Power MC, Palta P, Alonso A, Schneider AL, Perryman K, Bandeen-Roche K, Sharrett AR. Relationship of Cigarette Smoking and Time of Quitting with Incident Dementia and Cognitive Decline. Journal of the American Geriatrics Society. 2019 Nov 1.

[210]Diniz BS, Butters M a, Albert SM, Dew MA, Reynolds CF. Late-life depression and risk of vascular dementia and Alzheimer's disease: systematic review and meta-analysis of community-based cohort studies. Br J Psychiatry 2013; 202: 329-35

[211] Teodorczuk A, O'Brien JT, Firbank MJ, Pantoni L, Poggesi A, Erkinjuntti T, Wallin A, Wahlund LO, Gouw A, Waldemar G, Schmid R. White matter changes and late-life depressive symptoms: longitudinal study. The British Journal of Psychiatry. 2007 Sep;191(3):212-7. 
[212] Thomas AJ, O'Brien JT, Davis S, Ballard C, Barber R, Kalaria RN, Perry RH. Ischemic basis for deep white matter hyperintensities in major depression: a neuropathological study. Archives of general psychiatry. 2002 Sep 1;59(9):785-92.

[213] Snowden MB, Atkins DC, Steinman LE, Bell JF, Bryant LL, Copeland C, Fitzpatrick AL. Longitudinal association of dementia and depression. The American Journal of Geriatric Psychiatry. 2015 Sep 1;23(9):897-905.

[214]Killin LO, Starr JM, Shiue IJ, Russ TC. Environmental risk factors for dementia: a systematic review. BMC geriatrics. 2016 Dec;16(1):175.

[215]Bondy SC. Low levels of aluminum can lead to behavioral and morphological changes associated with Alzheimer's disease and agerelated neurodegeneration. Neurotoxicology. 2016 Jan 1;52:222-9.

[216]Walton JR. Chronic aluminum intake causes Alzheimer's disease: applying Sir Austin Bradford Hill's causality criteria. Journal of Alzheimer's Disease. 2014 Jan 1;40(4):765-838.

[217] Mahurkar S, Salta R, Smith E, Dhar S, Meyers JR L, Dunea G. Dialysis dementia. The Lancet. 1973 Jun 23;301(7817):1412-5.

[218]Alfrey AC, Mishell JM, Burks J, Contiguglia SR, Rudolph H, Lewin E, Holmes JH. Syndrome of dyspraxia and multifocal seizures associated with chronic hemodialysis. ASAIO Journal. 1972 Apr $1 ; 18(1): 257-61$.

[219]Russ TC, Killin LO, Hannah J, Batty GD, Deary IJ, Starr JM. Aluminium and fluoride in drinking water in relation to later dementia risk. The British Journal of Psychiatry. 2019 Mar 14:1-6.

[220]Exley,C. E.R. House ER.Aluminium in the human brain Monatsh. Chem., 1422011 pp. 357-363

[221] Mirza A, King A, Troakes C, Exley C. Aluminium in brain tissue in familial Alzheimer's disease. Journal of Trace Elements in Medicine and Biology. 2017 Mar 1;40:30-6

[222]ExleyC. What is the risk of aluminium as a neurotoxin? Expert Rev. Neurother., 142014 pp. 589-591.

[223]Forlenza OV, Diniz BS, Radanovic M, Santos FS, Talib LL, Gattaz WF. Disease-modifying properties of long-term lithium treatment for amnestic mild cognitive impairment: randomised controlled trial. $\mathrm{Br} J$ Psychiatry. 2011;198(5):351-356.

[224]Nunes MA, Viel TA, Buck HS. Microdose lithium treatment stabilized cognitive impairment in patients with Alzheimer's disease. Curr Alzheimer Res. 2013;10(1):104-107.

[225] Carey IM, Anderson HR, Atkinson RW, Beevers SD, Cook DG, Strachan DP, Dajnak D, Gulliver J, Kelly FJ. Are noise and air pollution related to the incidence of dementia? A cohort study in London, England. BMJ open. 2018 Sep 1;8(9):e022404.

[226]Paul KC, Haan M, Mayeda ER, Ritz BR. Ambient Air Pollution, Noise, and Late-Life Cognitive Decline and Dementia Risk. Annual review of public health. 2019 Apr 1;40:203-20.

[227] National Institute on Aging. BRAIN HEALTH: Medications' Effects on Older Adults' Brain Function. Accessed https://www.nia.nih.gov/sites/default/files/d7/MedAgeBrainBrochure.pdf

[228]Copersino ML, Fals-Stewart W, Fitzmaurice G, Schretlen DJ, Sokoloff J, Weiss RD. Rapid cognitive screening of patients with substance use disorders. Experimental and clinical psychopharmacology. 2009 Oct;17(5):337.

[229] Mackin, R.S. \& Arean, P.A. Incidence and documentation of cognitive impairment among older adults with severe mental illness in a community mental health setting. American Journal of Geriatric Psychiatry.2009, 17, 75- 82.

[230] Gøtzsche PC, Young AH, Crace J. Does long term use of psychiatric drugs cause more harm than good?. Bmj. 2015 May 12;350:h2435.

[231] Hayflick, L. Cell aging. Annual review of gerontology and geriatrics, 1980; 1, 26-67.

[232] Comfort A: The Biology of Senescence. London, Routledge and Kegan Paul, 1953.

[233] McCaulley, ME, Grush, KA. Alzheimer's disease: exploring the role of inflammation and implications for treatment. Int J Alzheimers Dis. 2015;2015:515248

[234]Cheng, X, Shen, Y, Li, R. Targeting TNF: a therapeutic strategy for Alzheimer's disease. Drug Discov Today. 2014;19:1822-1827.

[235] Soscia SJ, Kirby JE, Washicosky KJ, Tucker SM, Ingelsson M, Hyman BT, et al. The Alzheimer's disease-associated amyloid ß-protein is an antimicrobial peptide. PLoS ONE. 2010;5:e9505

[236] Watabe-Rudolph M, Song Z, Lausser L, et al. Chitinase enzyme activity in CSF is a powerful biomarker of Alzheimer disease. Neurology 2012; 78: 569- 577

[237]Finch CE, Sapolsky RM. The evolution of Alzheimer disease, the reproductive schedule, and apoe isoforms. Neurobiol Aging. 1999; 20:407-28.

[238]Fahlström A, Yu Q, Ulfhake B. Behavioral changes in aging female C57BL/6 mice. Neurobiol Aging. 2011; 32:1868-80. PubMed:
[239] Landsberg G, Araujo JA. Behavior problems in geriatric pets. Vet Clin Small Anim. 2005; 35:675-98

[240]Reser JE. Alzheimer's disease and natural cognitive aging may represent adaptive metabolism reduction programs. Behav Brain Funct. 2009; 5:13.

[241]Glass DJ, Arnold SE. Some evolutionary perspectives on Alzheimer's disease pathogenesis and pathology. Alzheimer's \& Dementia. 2012 Jul $1 ; 8(4): 343-51$

[242] Wozniak MA, Itzhaki RF, Faragher EB, James MW, Ryder SD, Irving WL. Apolipoprotein E- $€ 4$ protects against severe liver disease caused by hepatitis $\mathrm{C}$ virus. Hepatology. 2002 Aug:36(2):456-63.

[243]Ravaja N, Räikkönen K, Lyytinen H, Lehtimäki T, KeltikangasJärvinen L. Apolipoprotein E phenotypes and cardiovascular responses to experimentally induced mental stress in adolescent boys. Journal of behavioral medicine. 1997 Dec 1;20(6):571-87.

[244]Zetterberg H, Palmér M, Ricksten A, Poirier J, Palmqvist L, Rymo L, Zafiropoulos A, Arvanitis DA, Spandidos DA, Blennow K. Influence of the apolipoprotein E $\varepsilon 4$ allele on human embryonic development. Neuroscience Letters. 2002 May 24;324(3):189-92.

[245]Klaver CC, Kliffen M, van Duijn CM, Hofman A, Cruts M, Grobbee DE, van Broeckhoven C, de Jong PT. Genetic association of apolipoprotein $\mathrm{E}$ with age-related macular degeneration. The American Journal of Human Genetics. 1998 Jul 1;63(1):200-6.

[246] Wozniak MA, Riley EM, Itzhaki RF. Apolipoprotein E polymorphisms and risk of malaria. Journal of medical genetics. 2004 Mar 1;41(3):145-

[247]Hubacek JA, Pitha J, Skodová Z, Adámková V, Lánská V, Poledne R. A possible role of apolipoprotein E polymorphism in predisposition to higher education. Neuropsychobiology. 2001; 43:200-3.

[248] Morris BJ, Willcox BJ, Donlon TA. Genetic and epigenetic regulation of human aging and longevity. Biochimica et Biophysica Acta (BBA)Molecular Basis of Disease. 2019 Jul 1;1865(7):1718-44.

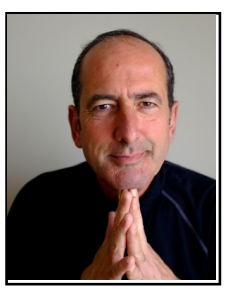

Mario Dominic Garrett, $\mathrm{Ph} . \mathrm{D}$, is professor of gerontology at San Diego State University, California, USA. Professor Garrett obtained his BSc (First Class Honors/summa cum laude) from the University of East London and his $\mathrm{PhD}$ from the University of Bath with an empirical thesis on loneliness. He has coordinated a U.N. five-year project looking at support system for older adults in the People's Republic of China. He founded the international aging magazine 'BOLD' (now the International Journal on Ageing in Developing Countries). In 1995 with the Minority Aging Research Institute at University of North Texas, Garrett was responsible for coordinating a statewide study on aging in all the nineteen pueblos in New Mexico. He has also designed and implemented training/educational courses in Pueblos and Reservations in the State of New Mexico as the Director of an educational program at the Center on Aging, University of New Mexico. As faculty at San Diego State University in 2004, he was the chairman of the department of gerontology and directed three research institutes. He has just published Coming of Age in Film with Cambridge Scholar Publishing. His website is mariogarrett.com 